\title{
Receptor Tyrosine Kinase-Mediated Angiogenesis
}

\author{
Michael Jeltsch ${ }^{1,2}$, Veli-Matti Leppänen ${ }^{1,2}$, Pipsa Saharinen ${ }^{1,2}$, and Kari Alitalo ${ }^{1,2,3,4}$ \\ ${ }^{1}$ Wihuri Research Institute, Biomedicum Helsinki, University of Helsinki, FIN-00014 Helsinki, Finland \\ ${ }^{2}$ Translational Cancer Biology Program, Biomedicum Helsinki, University of Helsinki, FIN-00014 \\ Helsinki, Finland \\ ${ }^{3}$ Institute for Molecular Medicine Finland, Biomedicum Helsinki, University of Helsinki, FIN-00014 \\ Helsinki, Finland \\ ${ }^{4}$ Helsinki University Central Hospital, Biomedicum Helsinki, University of Helsinki, FIN-00014 \\ Helsinki, Finland \\ Correspondence: kari.alitalo@helsinki.fi
}

\begin{abstract}
The endothelial cell is the essential cell type forming the inner layer of the vasculature. Two families of receptor tyrosine kinases (RTKs) are almost completely endothelial cell specific: the vascular endothelial growth factor (VEGF) receptors (VEGFR1-3) and the Tie receptors (Tie1 and Tie2). Both are key players governing the generation of blood and lymphatic vessels during embryonic development. Because the growth of new blood and lymphatic vessels (or the lack thereof) is a central element in many diseases, the VEGF and the Tie receptors provide attractive therapeutic targets in various diseases. Indeed, several drugs directed to these RTK signaling pathways are already on the market, whereas many are in clinical trials. Here we review the VEGFR and Tie families, their involvement in developmental and pathological angiogenesis, and the different possibilities for targeting them to either block or enhance angiogenesis and lymphangiogenesis.
\end{abstract}

\section{ANGIOGENESIS IN DEVELOPMENT \\ Basics of Vasculature}

Blood and lymph are the two major bodily fluids that transport and distribute, via the blood and lymphatic vessels, molecules and cells throughout the body. The essential building blocks of all vessels are endothelial cells (ECs). In the smallest vessels (capillaries), the vascular wall consists almost exclusively of ECs, whereas in larger vessels, and in particular the arteries, the vascular wall is multilayered, with the ECs forming the innermost layer (endothelium or the intimal layer). This is followed by a layer of smooth muscle/mural cells embedded in elastic connective tissue (media) and by the outer adventitial layer, which consists mainly of connective tissue (Boulpaep 2009). The growth of new blood vessels in the initially avascular embryo occurs via vasculogenesis, in which precursor cells from the mesoderm (hemangioblasts) aggregate and differentiate. In the yolk sac, cells in the periphery of the blood islands become ECs, whereas cells in the center differentiate into

Editors: Joseph Schlessinger and Mark A. Lemmon

Additional Perspectives on Signaling by Receptor Tyrosine Kinases available at www.cshperspectives.org

Copyright (C) 2013 Cold Spring Harbor Laboratory Press; all rights reserved; doi: 10.1101/cshperspect.a009183

Cite this article as Cold Spring Harb Perspect Biol 2013;5:a009183 
M. Jeltsch et al.

blood cells. A primitive vascular network is then established via sprouting angiogenesis (the growth of new blood vessels from pre-existing vessels) and extensive remodeling (Lugus et al. 2005). The contribution of vasculogenesis in the development of the lymphatic system has so far been shown only in birds (Papoutsi et al. 2001) and frogs (Ny et al. 2005), whereas in mammals, the lymphatic system may arise predominantly by a lymphangiogenic sprouting process that starts from the large veins (Wigle and Oliver 1999).

Vasculogenesis is largely restricted to early embryonic development, and angiogenesis is the major mechanism of vascular growth in later embryogenesis and in the adult. When new vessels start to grow, the ECs execute a complex program. They have to switch from their quiescent, immotile state into a proliferating, migrating state. A major trigger for this switch is hypoxia (insufficient oxygen concentration), which is often created by tissue expansion. An oxygensensing transcriptional system activates a genetic regulatory master switch, which engages the angiogenesis machinery.

Two RTK families - the VEGF receptors (VEGFRs) and the Tie receptors (Fig. 1)-are largely restricted to the ECs in vertebrates, although they also are expressed in a few other cell types, notably in some hematopoietic cells (listed in the supplementary information S2 in Olsson et al.2006). From the three VEGFRs, only two (VEGFR-2 and VEGFR-3) drive angiogenesis, whereas VEGFR-1 mostly acts to restrict the angiogenic response (Ho et al. 2012) and to recruit macrophages for tissue remodeling (Pipp et al. 2003). Under normal conditions, stimulation of VEGFR-2 results in angiogenesis of blood vascular ECs (BECs), whereas stimulation of VEGFR-3 elicits a similar response in lymphatic ECs (LECs). The Tie receptors have context-dependent roles in EC survival and in the stabilization and remodeling of blood and lymphatic vessels.

Two other RTK families play important roles in angiogenesis, namely the platelet-derived growth factor (PDGF) receptors and Eph receptors. The PDGF receptors are important for the stabilization of the vascular wall by mural cells, such as pericytes and smooth muscle cells (Andrae et al. 2008), and the Eph receptors are involved in determining arterial versus venous identity (Adams and Eichmann 2010). ECs normally do not express PDGF receptors, and the Eph receptors and their membrane-bound ligands (ephrins) are not exclusively expressed by endothelial cells. This paper will focus on the relatively EC-specific VEGF and Tie receptors.

\section{Blood versus Lymphatic Vasculature}

The cardiovascular system is a high-pressure system from which blood plasma continuously leaks out into tissues. The primary function of the lymphatic vessels is to drain this fluid and to return it into the blood circulation. On its path, the lymph, including its cellular elements, passes through one or several lymph nodes where it is scanned for foreign antigens; hence, the lymphatic system is essential for an efficient immune defense. In the intestine, lymphatic vessels serve yet another specialized function. They absorb long chain dietary triglycerides and other lipophilic compounds after their digestion and transport these in the form of chylomicrons to other parts of the body. The blood and lymphatic vessels are also structurally different; with the exception of fenestrated and discontinuous endothelia, BECs connect to each other via both tight and adherens junctions and form a continuous basement membrane on their abluminal side. LECs, on the other hand, are only loosely connected to each other and have a discontinuous basement membrane, relying on so-called anchoring filaments to connect to the pericellular matrix (Jeltsch et al. 2003).

Several molecular markers differ between BECs and LECs. Although both BECs and LECs carry panendothelial markers, such as plateletendothelial cell adhesion molecules (PECAM1 ), they express different subsets of RTKs. VEGFR-1 and VEGFR-2 are expressed by BECs, whereas VEGFR-2 and VEGFR-3 are expressed by LECs. However, VEGFR-3 is also expressed in discontinuous or fenestrated blood vascular endothelium (Partanen et al. 2000). Also the high endothelial venules (HEVs) that carry out important immune functions (Kaipainen et al. 


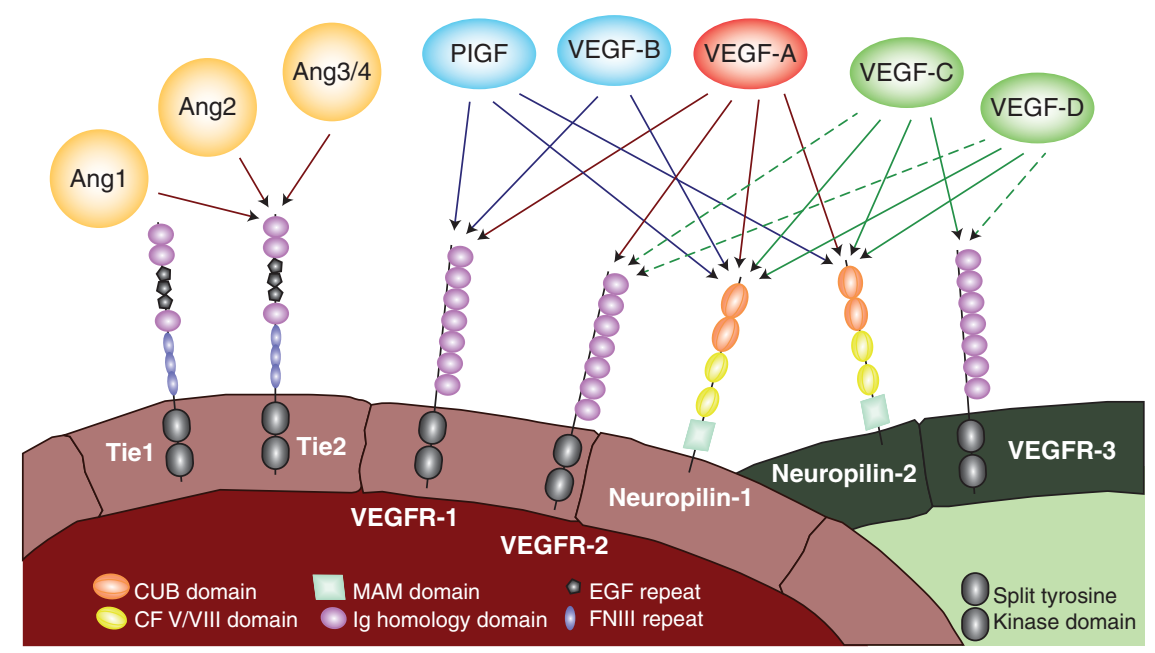

Figure 1. Schematic presentation of Tie and VEGF receptors and their ligands. There are five VEGFs and three angiopoietins in mammals (the mouse ortholog of Ang4 is also referred to as Ang3). Dotted lines indicate that the ligand-receptor interaction is weak or nonexistent for some isoforms of the ligand (Joukov et al. 1997; Baldwin et al. 2001; Leppanen et al. 2011). CUB, Clr/Cls, urchin EGF-like protein, and bone morphogenetic protein I; CF, coagulation factor; MAM, meprin/A5-protein/PTP $\mu$; Ig, immunoglobulin; EGF, epidermal growth factor; FN, fibronectin.

1995; Lacorre et al. 2004) and the abnormal vasculature of tumors can express VEGFR-3 (Tammela et al. 2008).

\section{Tip and Stalk Cells Express Different RTKs}

Some of the mechanisms of vessel sprouting in angiogenesis and lymphangiogenesis are surprisingly similar to neuronal axon guidance and the formation of the tracheal system in the fruit fly. The cell leading the EC migration toward a chemotactic stimulus, called the tip cell, sends out numerous filopodia in order to integrate attractive and repellent signals. Repulsive signals are mediated, for example, by the EphB4 RTK and its transmembrane ephrinB2 ligand; these inhibit the direct interaction between arterial and venous endothelial cells (Füller et al. 2003). Such behavior is analogous to functioning of the growth cones of nerve cells. Migration signals are mediated via VEGFR-2 and VEGFR-3 expressed by the tip cells. The Notch ligand Dll4 in the tip cells mediates lateral inhibition of sprouting to the adjacent cells (stalk cells) via Notch signaling. This in turn induces up-regulation of VEGFR-1 and down-regulation of both VEGFR-2 and VEGFR-3 in the stalk cells (Fig. 2)
(Jakobsson et al. 2009). Tip cells also express neuropilin-1, which appears essential for the tip cell functions. Neuropilin-1 acts as a coreceptor for VEGFR-2 and neuropilin-2 acts as a coreceptor for both VEGFR-2 and VEGFR-3 (Favier et al. 2006; Karpanen et al. 2006; Pan et al. 2007; Caunt et al. 2008; Xu et al. 2010). In order to achieve directed, hierarchical sprouting, a VEGF-A gradient is established around the cells producing VEGF-A. Different VEGF-A isoforms vary in their gradient-forming ability due to their different affinities to heparan sulfate proteoglycans on the cell surface and in the pericellular matrix (Ruhrberg et al. 2002). Eventually, tip cells need to detect and connect to neighboring sprouts to form perfused loops. This process is regulated by neuropilin signaling and macrophages that accompany angiogenic processes (Gerhardt et al. 2004; Fantin et al. 2010).

\section{MOLECULAR MECHANISMS OF ANGIOGENESIS}

\section{VEGF Receptors and Their Ligands}

The ligands of the VEGFRs, the mammalian vascular endothelial growth factors (VEGF- 
M. Jeltsch et al.

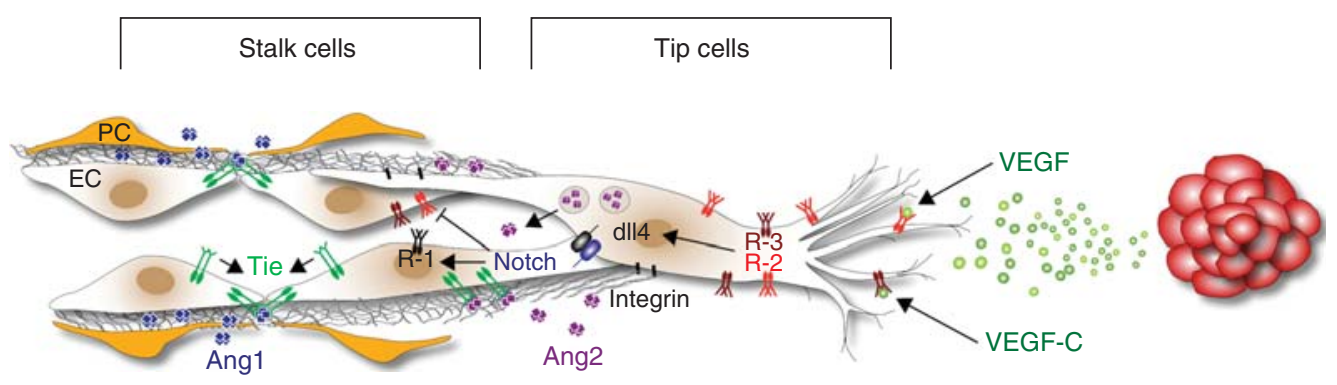

Figure 2. Schematic presentation of the involvement of RTKs in sprouting angiogenesis. VEGF-A and VEGF-C activate VEGFR-2 and VEGFR-3 in the tip cells of angiogenic sprouts, which leads to the migratory cell phenotype. Dll4, which is expressed in the tip cells, interacts with Notch on stalk cells to down-regulate VEGFR-2 and VEGFR-3 and to up-regulate VEGFR-1. Tip cells express Ang2, and may release Ang2 from the Weibel-Palade bodies promoting angiogenesis. Pericyte-produced and matrix-associated Ang1 stabilizes the stalk cells via cell-cell junctional Tie receptor complexes, promoting cell survival, matrix interactions, and endothelial barrier function. In the stalk cells, Ang2 may compete with Ang1, promoting vessel destabilization.

A, VEGF-B, VEGF-C, VEGF-D, and placenta growth factor [PlGF]) (Fig. 1) are crucial regulators of angiogenesis. Their activities are modulated through binding to the heparan sulfate proteoglycan and neuropilin coreceptors. VEGFRs are type-V RTKs comprising a family of transmembrane receptors with an extracellular part of seven immunoglobulin (Ig) homology domains (Fig. 1). VEGFRs utilize distinct Ig homology domains for ligand binding and dimerization. The VEGF family members are antiparallel homodimeric, secreted glycoproteins with multiple isoforms that are generated by alternative splicing and posttranslational processing. Characteristic for the VEGFRs and for most other RTKs is the dimerization of the extracellular domains upon ligand binding. The interactions of the membrane-proximal domains ensure correct positioning of the intracellular domains resulting in their autophosphorylation and downstream signaling (Koch et al. 2011). VEGFR-2 and VEGFR-3 contribute to Erk1,2 activation, whereas Akt activation is mostly induced by VEGFR-3 (Tvorogov et al. 2010; Koch et al. 2011).

Ligand binding to VEGFR-2 induces a robust tyrosine phosphorylation and results in a strong angiogenesis response (Waltenberger et al. 1994), whereas VEGFR-1 has only weak tyrosine kinase activity and seems to modulate angiogenesis as a decoy receptor (Ferrara 2004; Shibuya and Claesson-Welsh 2006; Ho et al.
2012). VEGF-A is a ligand for both VEGFR-2 and VEGFR-1, whereas VEGF-B and PlGF are VEGFR-1-specific ligands. Alternative splicing of both VEGFR-1 and VEGFR-2 gives rise to secreted receptor variants, which are able to bind their respective ligands and may inhibit angiogenesis and lymphangiogenesis (Kendall and Thomas 1993; Albuquerque et al. 2009).

VEGFR-3 and its primary ligand VEGF-C play important roles in the formation of the lymphatic vascular system (Tammela and Alitalo 2010). Upon removal of the propeptides, the VEGFR-3 ligands VEGF-C and VEGF-D acquire a strong binding affinity also for VEGFR2 and become angiogenic (Joukov et al. 1997; Stacker et al. 1999; Anisimov et al. 2009; Leppanen et al. 2011). VEGF-C activation of VEGFR-3 and ligand-induced VEGFR-3/ VEGFR-2 heterodimers are also important in sprouting angiogenesis (Tammela et al. 2008; Nilsson et al. 2010). Furthermore, VEGF-C-induced VEGFR-3 activation contributes to the phenotypic conversion of endothelial cells at fusion points of vessel sprouts (Tammela et al. 2011b).

\section{Tie Receptors and Their Ligands}

In addition to the VEGF-VEGFR system, the angiopoietin-Tie system is the second endothelial-specific RTK pathway involved in blood and lymphatic vessel development. The intracellular 
parts of Tie1 and Tie2 RTKs have a similar split tyrosine kinase domain as the VEGFRs (Partanen et al. 1992), whereas their extracellular domains are composed of two Ig homology domains, followed by three epidermal growth factor (EGF) homology domains, a third Ig homology domain, and three fibronectin type-III domains (Fig. 1) (Barton et al. 2006; Macdonald et al. 2006).

The angiopoietin growth factors (Ang1, Ang2, and Ang4) (Fig. 1) function as ligands for Tie2 (Davis et al. 1996; Maisonpierre et al. 1997; Kim et al. 1999; Valenzuela et al. 1999; Lee et al. 2004). The angiopoietins comprise a structurally unique family of growth factor ligands that multimerize to form various-sized multimers with multiple receptor-binding domains (Kim et al. 2005). The angiopoietins do not directly bind to Tie1, and therefore Tie1 is considered an orphan receptor. However, Ang1 and Ang 4 activate Tie1 in heteromeric receptor complexes in endothelial cells, which most likely involve the interaction between Tie1 and Tie2 (Saharinen et al. 2005; Seegar et al. 2010).

Activation of Tie 2 occurs via a unique mechanism, which is not used by other soluble growth factor ligands, and thus differs from, for example, VEGF-induced receptor activation (Fukuhara et al. 2008; Saharinen et al. 2008). When contacting ECs are stimulated with angiopoietins, the Tie2 receptors are rapidly translocated to EC-EC junctions to form homomeric Tie2 complexes that associate in trans across the EC-EC junctions (Fig. 2) (Fukuhara et al. 2008; Saharinen et al.2008). Tiel is associated with Tie2 and traffics also to these complexes (Saharinen et al.2008). The junctional Ang1-Tie2 complexes activate preferentially the phosphatidyl-inositol-3 kinase (PI3K)/Akt kinase pathway to promote cell survival, EC stability, and barrier function (Fukuhara et al. 2008; Saharinen et al. 2008). The junctional Tie 2 complexes are likely activated in the quiescent vasculature. In mobile ECs, matrix-bound Ang1 activates Tie2 in ECmatrix contacts to induce EC-matrix adhesion and cell migration via activation of the extracellular regulated kinases (Erk) (Fukuhara et al. 2008) and the adaptor protein DokR (Saharinen et al. 2008).
Receptor Tyrosine Kinase-Mediated Angiogenesis

Ang2 stimulation of ECs results in Tie2 translocation to EC-EC junctions, but, whereas Ang1 induces Tie2 activation, Ang2 induces only weak Tie2 tyrosine phosphorylation (Maisonpierre et al. 1997; Saharinen et al. 2008). Thus, Ang2 in some conditions acts as an antagonist to inhibit the more robust Ang1-induced Tie2 activation. Ang2 is stored in endothelial cell Weibel-Palade bodies, from where it is rapidly released in response to various stimuli (Fiedler et al. 2004). Ang2 levels are increased in tumor patients and in numerous diseases characterized by vascular leakage and inflammation, for example, in sepsis (Parikh et al. 2006). In the latter situations, Ang2 may compete with Ang1 in Tie2 binding, promoting EC destabilization and vessel regression. In tumors, Ang2 promotes angiogenesis and vascular sprouting, possibly acting as a Tie2 agonist (Holash et al. 1999; Hashizume et al. 2010; Daly et al. 2013).

Angiopoietins may also directly bind to integrins, and this may regulate the functions of tip cells, which express high levels of Ang2 but low Tie2 levels (del Toro et al. 2010; Felcht et al. 2012). The Tie2 receptor also interacts with integrins when endothelial cells adhere on fibronectin, sensitizing cells for Ang1 signaling (Cascone et al. 2005). Ang2 regulates Tie2 localization in an integrin-dependent manner (Pietila et al. 2012), and induces clustering of Tie2 and $\beta 3$ integrins in cell-cell junctions stimulating integrin turnover (Thomas et al. 2010).

\section{Endothelial Cell-Specific RTKs \\ in Development}

\section{VEGF Receptors}

VEGFR-2 is expressed in the early mesoderm in cells that undergo angioblast differentiation, and mice lacking VEGFR-2 die at embryonic day E8.5-9.5 as a result of defects in the development of hematopoietic and endothelial cells (Quinn et al. 1993; Shalaby et al. 1995). Mice lacking a single VEGF-A allele display abnormal blood vessel development and embryonic lethality before E9.5 (Carmeliet et al. 1996; Ferrara et al. 1996). VEGF-A and VEGFR-2 expression decrease postnatally, but expression is again up- 
M. Jeltsch et al.

regulated in tissues undergoing physiological or pathological angiogenesis (Ferrara 2004). In hypoxic cells, VEGF-A expression is up-regulated via the oxygen sensor system that works via the hypoxia-inducible transcription factor (HIF) (Germain et al. 2010).

Deletion of VEGFR-1 from mouse embryos results in a severely disorganized vasculature, which results from an increased commitment of mesenchymal precursor cells to the hemangioblast lineage (Fong et al. 1995, 1999). Similarly, VEGFR-1 deletion in adult vessels leads to increased angiogenesis (Ho et al. 2012). However, deletion of the tyrosine kinase domain of VEGFR-1 does not affect vascular development (Hiratsuka et al. 1998), nor does the deletion of its specific ligands VEGF-B or PlGF compromise mouse viability or lead to significant phenotypes in physiological conditions (Bellomo et al. 2000; Carmeliet et al. 2001). This has led to the view that VEGFR-1 and its soluble isoform (sVEGFR-1) act primarily by sequestering excess VEGF-A from its major receptor VEGFR-2 modulating endothelial cell proliferation (Kearney et al. 2002) and sprout formation (Chappell et al. 2009).

During early embryonic development, VEGFR-3 is expressed widely in the ECs but thereafter it becomes gradually restricted to the developing lymphatic vessels (Kaipainen et al. 1995). VEGFR-3-deficient mice die at E9.5 due to defective remodeling and maturation of blood vessels prior to the development of lymphatic vessels (Dumont et al. 1998). VEGF-Cdeficient mice die about 3 days later due to edema upon failure of the lymphatic vessel development (Karkkainen et al. 2004). In contrast, the lymphatic vascular development is not affected in VEGF-D-deficient mice (Baldwin et al. 2005). Strikingly, loss of both VEGFR-3 ligands, VEGF-C and VEGF-D, fails to reproduce the early embryonic lethality of VEGFR-3-deficient mice (Haiko et al. 2008). One explanation for this may be that the VEGFR-3-matrix/integrin interactions are sufficient for the early embryonic development (Zhang et al. 2005; Galvagni et al. 2010). In addition, the collagen and calcium-binding EGF domains 1 protein (CCBE1) enhances VEGF-C-induced lymphangiogene- sis and is also important for lymphatic vascular development (Hogan et al. 2009; Bos et al. 2011; Hagerling et al. 2013).

\section{The Ang/Tie System}

The Ang-Tie system is required for the remodeling of the developing blood and lymphatic vasculatures after their initial assembly regulated by the VEGFs (Augustin et al. 2009).

Tie $2^{-/-}$mouse embryos show severely impaired cardiac development, hemorrhages, and reduced numbers of endothelial cells, resulting in the death of the embryos by E10.5 (Dumont et al. 1994). The gene-targeted embryos deficient of the Tie2 ligand Ang1 have a very similar phenotype, including impaired cardiac development and defective remodeling of the primary vascular plexus, resulting in embryonic lethality (Suri et al. 1996). In addition, the ECs of the Ang1 ${ }^{-/-}$ embryos are rounded and poorly associated with basement membranes. Ang1 is dispensable in the adult vasculature during normal homeostasis, but it is required to limit angiogenesis in pathological processes. Conditionally, Ang1-targeted mice develop excessive tissue fibrosis upon vascular stress, suggesting that Ang1 limits perivascular fibrosis, perhaps counteracting TGF- $\beta$ signaling (Jeansson et al. 2011).

The Tie $1^{-/-}$mouse embryos have impaired endothelial integrity and hemorrhages, resulting in lethality starting around E13.5, and the deletion of both Tie1 and Tie 2 results in a similar, but more severe phenotype than that of the Tie $2^{-/-}$ embryos (Puri et al. 1995; Sato et al. 1995). Embryos chimeric for the gene-targeted Tiel and Tie2 alleles showed that Tiel and Tie2 are cellautonomously required for EC survival in the microvasculature during late embryogenesis and in essentially all blood vessels in the adult (Partanen et al. 1996; Puri et al. 1999). Tiel is also critical for lymphatic development; the jugular lymph sacs of Tie $1^{-/}$mouse embryos appear malformed, and the embryos are swollen, before any signs of blood vascular defects (D’Amico et al. 2010; Qu et al. 2010).

The Ang $2^{-/-}$mice die postnatally or, depending on the background, survive until adulthood. The surviving Ang $2^{-/-}$mice accumulate 
chylous ascites due to malfunctioning lymphatic vessels, which are abnormally attached to the smooth muscle cells (Gale et al. 2002; Dellinger et al. 2008). The blood vascular defects of Ang $2^{-/-}$mice are limited to the vitreous vessels. However, ectopic overexpression of Ang2 in developing mouse embryos results in embryonic lethality and a vascular phenotype similar to that of Ang1 ${ }^{-/-}$embryos, suggesting that at least in certain circumstances Ang2 may act as an antagonist of Ang1 (Maisonpierre et al. 1997) despite being an agonist of Tie2 in others (Daly et al. 2013).

\section{ANGIOGENESIS IN DISEASE}

The endothelial cells of healthy adult organisms are largely quiescent. Notable exceptions-accompanied by local increases in VEGF-A and VEGF-A receptor expression-include wound healing and tissue repair (Tonnesen et al. 2000), exercise-induced angiogenesis in the heart and skeletal muscle (Prior et al. 2004), the hair cycle (Yano et al. 2001), and, in the female, reproductive cycle and placenta development (Augustin 2005). Pathological angiogenesis differs from physiological angiogenesis, which is tightly controlled and spatially and temporally limited. Pathological angiogenesis plays an important role in many diseases, notably in tumor development.

\section{Angiogenesis and Tumor Development \\ Tumor Angiogenesis and Tumor Lymphangiogenesis}

The concept that tumors are angiogenesis dependent has led to multiple attempts of therapeutic intervention. In several tumor models, the initial stages of tumor growth occur without the involvement of blood vessels until oxygen diffusion becomes limiting and the hypoxic tumor cells start to stimulate vessel growth. This event is called the "angiogenic switch" and it can occur already in the premalignant stages of tumor development (Hanahan et al. 1996; Baeriswyl and Christofori 2009).

VEGF-A/VEGFR-2 is the major growth factor axis involved in tumor angiogenesis (Fer-
Receptor Tyrosine Kinase-Mediated Angiogenesis

rara et al. 2007). The role of VEGF-A in tumor angiogenesis was validated by experiments showing that angiogenesis in tumors and, subsequently, tumor growth could be inhibited by VEGF-A-blocking antibody therapy (Kim et al. 1993). The anti-VEGF-A monoclonal antibody Bevacizumab (Avastin) was the first antiangiogenic cancer drug targeting this axis. However, not all tumors are sensitive to antiangiogenic therapy (intrinsic resistance), and most sensitive tumors will eventually become resistant (evasive resistance) (Abdullah and Perez-Soler 2011; Sennino and McDonald 2012; Singh and Ferrara 2012). A tumor could competitively circumvent VEGF-A inhibition by increasing its VEGF-A production or by switching to an alternative ligand or receptor. For example, VEGFR-3, which is expressed in the tumor vasculature, can be activated by VEGF-C or VEGF-D and after their proteolytic processing, these factors can additionally activate VEGFR-2 (Tammela et al. 2008; Anisimov et al. 2009). Whether PlGF can drive tumor angiogenesis has been controversial, also due to the fact that the PlGF receptor VEGFR-1 appears to be a negative regulator of angiogenesis (Bais et al. 2010; Van de Veire et al. 2010). However, VEGFR-1 is expressed in certain tumor types, and in a fraction of mononuclear phagocytes that contribute other signals for tumor angiogenesis (Bais et al. 2010). Additional mechanisms of resistance to VEGF-A blocking include vessel co-option (Huang et al. 2009), recruitment of myeloid cells from the bone marrow (Ferrara 2010), and other angiogenic factors, such as fibroblast growth factors (FGFs) (Nissen et al. 2007). Targeting multiple angiogenic pathways may lead to improved efficacy of antiangiogenic therapy.

Tumor vasculature is far from normal; it is very heterogeneous and leaky, and shows a lack of hierarchical organization. Hence, blood flow is slow and the interstitial pressure inside the tumor is high, making it difficult for cytostatic drugs to reach their target cells. The current antiangiogenic drugs reduce tumor blood vessels, resulting in the "normalization" of the remaining vasculature, with less vascular leakiness, and improved pericyte coating and blood flow (Jain 2005). 
M. Jeltsch et al.

The angiopoietin-Tie system is also involved in tumor vascularization (see section on Targeting Angiopoietin Signaling). Ang1 has been implicated in the process of tumor vessel normalization during VEGF or Ang2-blocking therapies in mouse models (Winkler et al. 2004; Falcon et al. 2009), whereas Ang2 appears to directly stimulate tumor vascularization. Ang2 is thought to destabilize tumor co-opted blood vessels, resulting in hypoxia and enhanced VEGF-A expression, and the initiation of a neoangiogenic switch (Holash et al. 1999). Ang2 also stimulates sprouting angiogenesis together with VEGF-A (Hashizume et al. 2010).

\section{Hematogenous and Lymphatic Metastasis}

Tumors can metastasize via the blood vessels (hematogenous metastasis) or the lymphatic vessels (lymphatic metastasis). Tumor vascularization correlates with hematogenous metastasis (Weidner et al. 1991; Graeber et al. 1996) and VEGF-A or VEGFR-2 have provided prognostic markers for metastasis in some studies (Bremnes et al. 2006). VEGF-C and VEGF-D stimulate intratumoral and tumor-associated lymphangiogenesis and lymphatic metastasis (Stacker et al. 2002; He et al. 2004; Alitalo 2011). Intratumoral lymphatic vessels are rare and mostly nonfunctional, but they can be detected in several human tumors and at least in some studies their number correlated with VEGF-C and VEGF-D expression and clinical outcome (Achen and Stacker 2008). Most of the tumor-associated lymphatic vessels develop in the tumor periphery; they are recruited from the surrounding lymphatic vasculature (Karpanen et al. 2001; He et al. 2004, 2005), and facilitate tumor dissemination via the lymphatic vessels. Furthermore, VEGF-A and VEGF-C both promote collecting lymph vessel enlargement, increased lymph flow, lymph node lymphangiogenesis, and lymphatic metastasis ( $\mathrm{He}$ et al. 2002; Roberts et al. 2006; Tammela et al. 2011a).

Recently, Ang2 was shown to increase tumor lymphangiogenesis (Holopainen et al. 2012), as well as metastasis to lymph nodes and distant organs, and its blocking using anti- bodies inhibited the metastasis (Holopainen et al. 2012). The mechanisms likely involve tumor-associated Tie2-expressing macrophages (TEMs) (Mazzieri et al. 2011), and direct effects on endothelial integrity (Holopainen et al. 2012).

\section{Insufficient Angiogenesis in Ischemia}

Angiogenesis is one of the hallmarks of malignant tumors and an etiological agent in diseases such as diabetic retinopathy and age-related macular degeneration (AMD). On the other hand, chronic ischemic diseases are characterized by a surprising absence or insufficiency of the angiogenic response to local hypoxia. For example, in coronary artery disease, the formation of new collateral blood vessels to bypass the sclerotic arteries would obviously be beneficial for the patient; however, this process, arteriogenesis, and angiogenesis appear insufficient in most of such cases.

Several trials have attempted to stimulate collateral vessel growth and repair (Zachary and Morgan 2011). The most straightforward approach has been to apply growth factors that directly activate VEGFRs and thus stimulate EC proliferation. Early on, clinical trials appeared to demonstrate the beneficial effect of both VEGF-A and VEGF-C therapy in cardiovascular disease. However, this strategy to improve cardiovascular function has not been translated into clinical practice (Losordo et al. 2002; Reilly et al. 2005; Stewart et al. 2009; Vuorio et al. 2012). The VEGFR-1 ligands PlGF and VEGF$\mathrm{B}$ have both been proposed to play important roles during ischemic revascularization, especially in the heart. In mice, PlGF deletion impaired angiogenesis during ischemia (Carmeliet et al. 2001; Luttun et al. 2002). VEGF-B-stimulated coronary artery growth in transgenic rats (Bry et al. 2010), and deletion of VEGF-B in mice resulted in reduced heart size and vascular dysfunction after transient coronary occlusion as well as impaired recovery from experimentally induced myocardial ischemia (Bellomo et al. 2000; Li et al. 2008b) and VEGF-B-stimulated coronary artery growth in transgenic rats (Bry et al. 2010). 
Receptor Tyrosine Kinase-Mediated Angiogenesis

It is possible that other growth factor and cytokine signals are required in addition to VEGF signals to achieve significant therapeutic angiogenesis. Supporting this concept, a designed VEGF-angiopoietin growth factor chimera was superior to VEGF in inducing therapeutic angiogenesis with improved perfusion and less leakage in a mouse model of limb ischemia (Anisimov et al. 2013). On the other hand, the failures could be due to shortcomings in study design or technology (Ylä-Herttuala 2009). In order to activate a multiplicity of proangiogenic stimuli, gene therapy with upstream angiogenic master switches, such as HIF, has been proposed (Kim et al. 2009).

Lack of Lymphangiogenesis in Lymphedema

Lymphedema (insufficient lymphatic drainage) may be caused by deficient lymphangiogenesis, or lymphatic valve deficiency (Alitalo 2011; Norrmén et al. 2011). A relatively common cause of type-I hereditary lymphedema (Milroy disease) is lymphatic vessel hypoplasia due to decreased signaling by a VEGFR-3 allele having a missense point mutation inactivating the kinase domain (Karkkainen et al. 2000). Interestingly, although all ECs carry the mutant allele, it mostly affects the peripheral lymphatic capillaries, which are severely hypoplastic or absent (Bollinger et al. 1983). In one pedigree, a mutation in the coding region of the VEGF-C gene has been shown to cosegregate with the lymphedema phenotype (Gordon et al. 2013). Another rare cause of lymphedema is a mutation in the CCBE1 gene (Alders et al. 2009), which results in compromised VEGF-C-induced lymphangiogenesis (Hogan et al. 2009; Bos et al. 2011). A somewhat similar phenotype is observed in mice when VEGFR-3 signaling is inhibited (Makinen et al. 2001). However, therapeutic dosing of VEGF-C resulted in sufficient activation of VEGFR-3 and rescued the disease phenotype in mice (Karkkainen et al. 2001). Treating lymphedema by activating the primarily lymphangiogenic VEGF-C/VEGFR-3 axis has been also proposed as a rational therapy for secondary lymphedema, which is commonly caused by lymphatic vessel damage by surgery, infectious diseases, or traumas (Tammela et al. 2007; Alitalo 2011).

\section{Role of Ang2 Signals in Inflammation}

Tissue inflammation commonly stimulates angiogenesis and lymphangiogenesis. Blood and lymphatic vessels are conduits for immune cell trafficking and, when activated, the inflammatory cells produce a plethora of cytokines, including VEGFs, proteases, and growth factors that directly act on ECs promoting vascular permeability and angiogenesis. Not surprisingly, angiogenesis and often also lymphangiogenesis characterize a variety of chronic inflammatory diseases (e.g., rheumatoid arthritis, psoriasis, and some autoimmune and other disorders with inflammatory features such as obesity and diabetic retinopathy) (Costa et al. 2007; Alitalo 2011). Although angiogenesis is not the underlying cause in these disorders, antiangiogenic intervention could prove beneficial.

Ang2 is locally released from the secretory storage granules at sites of endothelial activation, and it acts as a proinflammatory molecule by sensitizing the endothelium, for example, to the tumor necrosis factor- $\alpha$-induced expression of endothelial cell adhesion molecules (Fiedler et al. 2006). In a mouse model of chronic airway inflammation, Ang2-blocking agents decreased the remodeling of mucosal capillaries into venules, the amount of leukocyte influx, and disease severity (Tabruyn et al. 2010).

In the pathogenesis of diabetic retinopathy, Ang2 is up-regulated in the endothelium and seems to induce the loss of pericytes from the retinal vasculature. Reducing the Ang2 levels inhibited diabetes-induced pericyte loss and decreased the number of acellular capillary segments (Hammes et al. 2004).

Ang2 may also directly act on endothelial cell-cell junctions to promote vascular leakage. The levels of Ang2 increase in a number of human diseases associated with inflammation and characterized by microvascular leakage, including sepsis and the acute respiratory distress syndrome. Notably, Ang2 induction precedes and contributes to the adverse outcomes in sepsis, suggesting that it is possible to target Ang2 in 
M. Jeltsch et al.

this condition (Parikh et al. 2006; David et al. 2012). In murine models, Ang1 has beneficial effects on alleviating vascular dysfunction, and some of the effects of Ang1 are likely mediated via its ability to reduce vessel permeability by reducing gaps between the ECs (Baffert et al. 2006; Li et al. 2008a). Furthermore, Ang1 also inhibits excessive angiogenesis, and pathological tissue fibrosis in various murine disease models (Jeansson et al. 2011).

\section{Endothelial Cell-Derived Tumors and Vascular Malformations}

A common EC-derived tumor is infantile hemangioma, in which rapidly proliferating endothelial cells give rise to a vascular lesion that can vary from small and innocuous to large and deforming. However, infantile hemangiomas regress spontaneously within several years and treatment is reserved for cases of significant cosmetic and functional interference and complications (North et al. 2006). Although their pathogenesis is still poorly understood, local dysregulation of angiogenesis involving hypoxia-mediated changes in VEGF and VEGFR expression seem to have an important etiological role in hemangiomas (Kleinman et al. 2007; Przewratil et al. 2010). Lymphangiomas, on the other hand, are vascular malformations involving lymphatic vessels, and they seem to be exclusively sporadic unlike capillary and venous malformations, which exist in both sporadic and hereditary forms (Brouillard and Vikkula 2007).

Mutations that increase the ligand-independent autophosphorylation of Tie2 have been identified as an important cause of inherited cutaneomucosal venous malformations, whereas somatic mutations cause more common sporadic lesions (Vikkula et al. 1996; Limaye et al. 2009). Contrary to epithelial cell-derived tumors (carcinomas), endothelial cell-derived tumors are mostly benign and the pathogenesis of their rare malignant counterparts (hemangiosarcoma or lymphangiosarcoma) is unclear. Interestingly, such tumors occur as a complication of postmastectomy edema (Janse et al. 1995). Kaposi's sarcoma is a more frequent tumor that is thought to arise from human her- pesvirus-8-induced reprogramming of lymphatic ECs (Liu et al. 2010).

\section{ANTIANGIOGENIC THERAPIES}

\section{Inhibitors Targeting the VEGF Signaling} Pathways

Up-regulation of certain VEGF family members and their receptors has been implicated in the pathogenesis of the majority of human tumors. Blocking antibodies against VEGF-A have shown the clinical utility of VEGF targeting in antiangiogenic tumor therapy (Hurwitz et al. 2004). Tumor growth inhibition has also been demonstrated with small molecule inhibitors of VEGFRs, anti-VEGFR antibodies, and soluble VEGF-A decoy receptors. However, despite a clear tumor control benefit in clinical trials the response to antiangiogenic therapy is often limited, and relapse of the disease follows (Sennino and McDonald 2012; Singh and Ferrara 2012). In such cases simultaneous targeting of multiple angiogenic pathways may provide improved therapeutic efficacy in the future. Table 1 lists antiangiogenic drugs in clinical use, or in clinical trials targeting VEGFs, VEGFRs, and angiopoietins, and Figure 3 shows a schematic view of the drugs and the drug targets.

\section{Small Molecule VEGFR Tyrosine Kinase Inhibitors}

Small molecule receptor tyrosine kinase inhibitors (TKIs) are typically ATP analogs with limited specificity. A number of small molecule inhibitors, including sorafenib, sunitinib, and pazopanib, have been described that inhibit the intrinsic tyrosine kinase activity of VEGFRs (Bhargava and Robinson 2011). However, these multitargeted agents inhibit a wide range of kinases in addition to the VEGFRs, and they are associated with adverse effects, some of which may be unrelated to efficient blocking of VEGF signaling. More selective, second-generation VEGFR TKIs tivozanib, axitinib, and cediranib are currently under evaluation. Extensive preclinical and clinical studies using VEGFR TKIs have shown that these second- 
Receptor Tyrosine Kinase-Mediated Angiogenesis

\begin{tabular}{|c|c|c|c|c|}
\hline Drug & Mechanism & Status & Application area & References \\
\hline $\begin{array}{l}\text { Bevacizumab } \\
\text { (Avastin) }\end{array}$ & VEGF-A antibody & Approved & Multiple types of cancer & $\begin{array}{l}\text { Ferrara et al. 2005; } \\
\text { Van Meter and Kim } \\
2010\end{array}$ \\
\hline $\begin{array}{l}\text { Ranibizumab } \\
\text { (Lucentis) }\end{array}$ & Pan-VEGF-A antibody & Approved & $\begin{array}{l}\text { Age-related macular } \\
\text { degeneration }\end{array}$ & $\begin{array}{l}\text { Rosenfeld et al. 2006; } \\
\text { Nguyen et al. } 2012\end{array}$ \\
\hline $\begin{array}{l}\text { Pegaptanib } \\
\quad \text { (Macugen) }\end{array}$ & $\begin{array}{l}\text { VEGF-A-neutralizing } \\
\text { aptamer }\end{array}$ & Approved & $\begin{array}{l}\text { Age-related macular } \\
\text { degeneration }\end{array}$ & $\begin{array}{l}\text { Ng et al. 2006; Virgili } \\
\text { et al. } 2012\end{array}$ \\
\hline Sorafenib & Multikinase inhibitor & Approved & Liver and kidney cancer & Escudier et al. 2007 \\
\hline Sunitinib & Multikinase inhibitor & Approved & Multiple cancer types & Motzer et al. 2007 \\
\hline Pazopanib & Multikinase inhibitor & Approved & $\begin{array}{l}\text { Renal cell carcinoma, soft } \\
\text { tissue sarcoma }\end{array}$ & Sleijfer et al. 2009 \\
\hline $\begin{array}{l}\text { VEGF-A Trap } \\
\quad(\text { aflibercept })\end{array}$ & $\begin{array}{l}\text { VEGF-A-neutralizing } \\
\text { receptor fragment }\end{array}$ & Approved & $\begin{array}{l}\text { Age-related macular } \\
\text { degeneration, oxaliplatin- } \\
\text { refractory metastatic } \\
\text { colorectal cancer }\end{array}$ & $\begin{array}{l}\text { Holash et al. 2002; } \\
\text { Teng et al. } 2010\end{array}$ \\
\hline Axitinib & VEGFR kinase inhibitor & Phase III & Renal cell carcinoma & $\begin{array}{l}\text { Bhargava and } \\
\text { Robinson } 2011\end{array}$ \\
\hline Tivozanib & $\begin{array}{l}\text { VEGFR/PDGFR kinase } \\
\text { inhibitor }\end{array}$ & Phase III & Renal cell carcinoma & $\begin{array}{l}\text { De Luca and } \\
\text { Normanno 2010; } \\
\text { Bhargava and } \\
\text { Robinson } 2011\end{array}$ \\
\hline AMG 386 & $\begin{array}{l}\text { Ang1/2-inhibiting } \\
\text { peptibody }\end{array}$ & Phase III & Multiple types of cancer & Coxon et al. 2010 \\
\hline Cediranib & Kinase inhibitor & Phase I/II & Multiple types of cancer & $\begin{array}{l}\text { Lindsay et al. 2009; } \\
\text { Bhargava and } \\
\text { Robinson } 2011\end{array}$ \\
\hline $\begin{array}{l}\text { CovX-body } \\
\quad(\text { COV-060) }\end{array}$ & Ang2 Trap & Phase I/II & Renal cell carcinoma & Huang et al. 2011 \\
\hline MEDI3617 & Ang2 antibody & Phase I/II & Multiple types of cancer & Brown et al. 2010 \\
\hline VGX-100 & VEGF-C antibody & Phase I & Multiple types of cancer & Goyal et al. 2012 \\
\hline CEP-11981 & $\begin{array}{l}\text { Tie/VEGF-AR kinase } \\
\text { inhibitor }\end{array}$ & Phase I & Multiple types of cancer & Hudkins et al. 2012 \\
\hline
\end{tabular}

generation VEGFR TKIs are capable of slowing the growth of primary tumors while having reduced off-target toxicities (Bhargava and Robinson 2011).

\section{VEGFR Ligand Inhibitors}

Targeting the VEGF axis for antiangiogenic tumor therapy was initially demonstrated by using a monoclonal antibody specific for VEGF-A, which inhibited the tumor growth by decreasing the density of tumor blood vessels (Kim et al. 1993). Subsequently, the humanized antiVEGF-A antibody bevacizumab was developed as the first antiangiogenic agent approved for clinical use in combination with chemotherapy for the treatment of metastatic colorectal cancer (Hurwitz et al. 2004; Ferrara et al. 2005). Ranibizumab, a recombinant humanized monoclonal antibody Fab fragment against VEGF-A, derived from bevacizumab, is being used for the treatment of age-related macular degeneration (AMD) (Rosenfeld et al. 2006). Antibodies against PlGF have been tested in preclinical models, but the results are controversial concerning the role of PlGF in tumor growth control (Bais et al. 2010; Van de Veire et al. 2010; Snuderl et al. 2013). Antibodies blocking VEGF-C have shown tumor growth inhibition in preclinical models and VEGF-C-blocking an- 
M. Jeltsch et al.

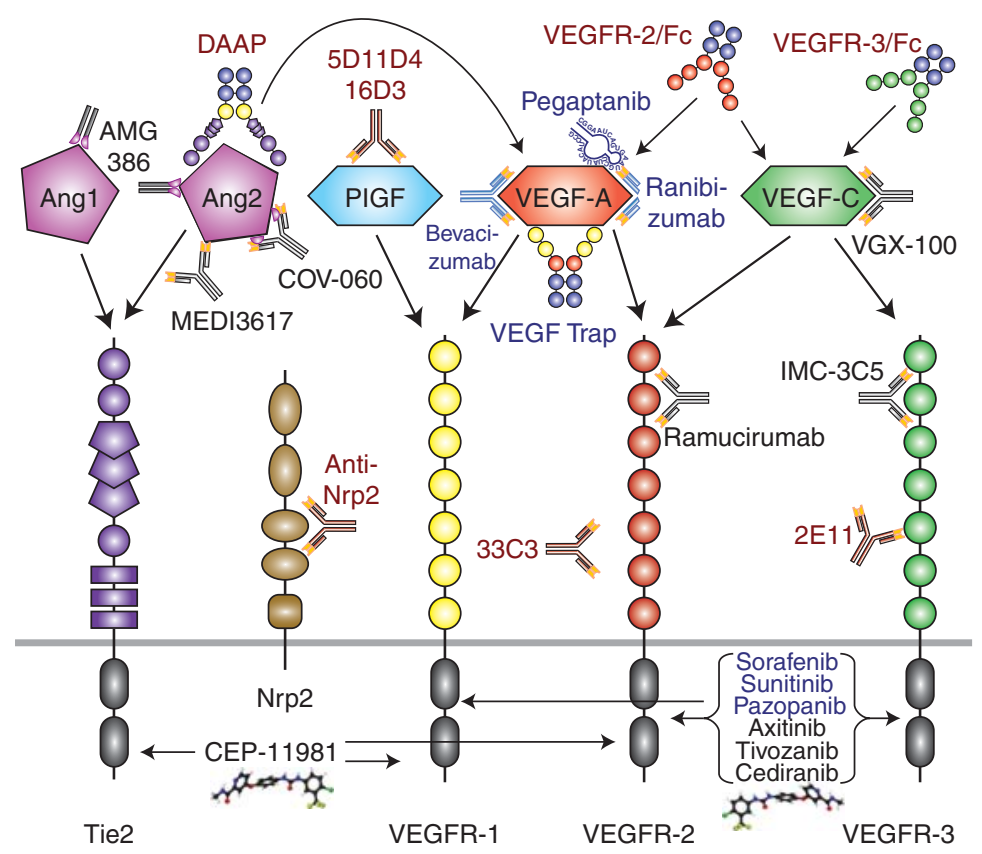

Figure 3. Schematic presentation of inhibitors of the VEGF and Tie pathways. Inhibitors approved by the FDA for clinical use are indicated in blue. Inhibitors that are currently tested in clinical trials are indicated in black and preclinical and nonclinical inhibitors in red.

tibodies are currently being tested in phase-I clinical trials (VGX-100) (Goyal et al. 2012).

Soluble decoy receptors represent a complementary way to block VEGF signaling pathways by preventing the ligands from binding to their cell-surface receptors. One decoy receptor with a high affinity for VEGF-A is a fusion of the VEGFR-1 ligand-binding domains to an Ig constant region, Flt(1-3)-IgG (Gerber et al. 2000). Also, a VEGFR-1/VEGFR-2 fusion protein, VEGF-A-Trap, was described as a potent anti-VEGF-A suppressor of tumor growth and vascularization in vivo (Holash et al. 2002). In recent comparisons of VEGF-A inhibitors, VEGF-A-Trap and Flt(1-3)-IgG had very similar potencies in the bioassays tested and they were both over 10-fold more potent than bevacizumab (Yu et al. 2011; Papadopoulos et al. 2012). In 2011, VEGF-A-Trap received FDA approval for the treatment of wet AMD and recently also for the treatment of oxaliplatinrefractory metastatic colorectal cancer (see www. fda.gov/Drugs/InformationOnDrugs/Approv edDrugs).
Results of studies using mouse tumor models have suggested that the inhibition of tumorderived VEGF-C with antibodies or a soluble VEGFR-3 decoy receptor represents another possible strategy for blocking of lymphatic metastasis (Lin et al. 2005). A soluble VEGFR-2 RNA splice variant has also been described as a VEGF-C-specific endogenous inhibitor of lymphatic vessels (Albuquerque et al. 2009).

\section{VEGF Receptor-Blocking Antibodies}

VEGFR activation requires ligand binding and dimerization. In principle, VEGFR activation and signaling can be inhibited either by blocking the ligand-binding site or by blocking receptor dimerization. Current VEGFR-2- and VEGFR3-blocking antibodies under clinical trials are potent inhibitors of ligand binding ( $\mathrm{Lu}$ et al. 2003; Persaud et al. 2004). In theory, targeting VEGF receptors (which have multiple ligands) should be superior to blocking a single ligand. Receptor-blocking antibodies need to compete with the ligand for binding to the VEGFR. This 
is less of a problem with receptor-blocking antibodies that prevent receptor dimerization (Tvorogov et al. 2010; Kendrew et al. 2011; Hyde et al. 2012), and some of these may also promote incremental inhibition in combination with antibodies targeted against the VEGFR ligand-binding site. Recent results have furthermore indicated that simultaneous VEGFR-2 and VEGFR-3 inhibition results in additive inhibition of tumor angiogenesis (Tammela et al. 2008). Neuropilin coreceptors have been suggested as additional targets for tumor therapy (Caunt et al. 2008).

\section{Targeting Angiopoietin Signaling}

Because of its intricate and context-dependent mechanism of action, the Tie-Ang axis has only recently become a target of antiangiogenic drug development. Tumor and stromal cells express Ang1, whereas Ang2 is predominantly produced by activated ECs (Augustin et al. 2009). Ang2 is readily induced in ECs of tumor co-opted blood vessels (Holash et al. 1999), and in the absence of VEGF-A, Ang2 induces endothelial destabilization and vessel regression, leading to an avascular tumor that is highly hypoxic. This results in increased expression of both Ang2 and VEGF-A, which promote the angiogenic switch in the tumor. Interestingly, one recent study showed that low Ang2 expression levels in the tumor stroma of metastatic colorectal cancer patients were associated with better response rates to VEGFblocking antibodies combined with chemotherapy (Goede et al. 2010).

A number of studies carried out in various preclinical murine models have shown that blocking Ang2 or both Ang1 and Ang2 significantly inhibits tumor growth and angiogenesis (for original articles, see Saharinen et al. 2011). Blocking Ang2 resulted in normalized tumor vessels with increased levels of adhesion molecules in EC-EC junctions, increased pericyte coverage, and reduced EC sprouting and vascular remodeling, resulting in smaller, more uniform vessels (Falcon et al. 2009). In line with these results, tumors grown in Ang $2^{-/-}$mice displayed a more mature vascular phenotype with increased numbers of pericytes and a small-
Receptor Tyrosine Kinase-Mediated Angiogenesis

er vessel diameter than tumors in wild-type mice (Nasarre et al. 2009). In addition, Ang2 overexpression induced a switch of the vascular phenotype of a breast cancer xenograft by inducing intratumoral hemorrhages and nonfunctional and abnormal blood vessels with increased EC apoptosis and decreased PC coverage (Reiss et al. 2009). At least one study suggests that in combination with Ang2 inhibition, Ang1-blocking agents may prevent tumor vessel normalization (Falcon et al. 2009). Accordingly, COMP-Ang1, a recombinant Ang1 protein, induced vessel normalization and improved vessel perfusion and thereby potentiated the effects of chemotherapy in a Lewis lung carcinoma isograft model (Hwang et al. 2009). The tumor vessel normalization that occurs during VEGF-A blockage may also be mediated in part by Ang1 (Winkler et al. 2004).

In addition to its autocrine functions in the ECs, Ang2 modulates the proangiogenic properties of TEMs, which have been shown to contribute to tumor progression (Mazzieri et al. 2011). Thus, the protumorigenic and proangiogenic functions of Ang2 may involve multiple mechanisms.

Although agents that block the VEGF-A pathway were recently reported to induce invasive growth of some tumors in mice (Ebos et al. 2009; Pàez-Ribes et al. 2009), no such effects have been observed in studies testing Ang2blocking antibodies. In contrast, Ang2-blocking antibodies inhibited the metastatic colonization of the lungs by tumor cells in mouse models, and subsequent metastatic growth (Mazzieri et al. 2011; Holopainen et al. 2012). The former was at least partially due to enhanced endothelial integrity and improved cell-cell junctions of pulmonary capillaries in Ang2-blocking antibody-treated mice (Holopainen et al. 2012).

The combination of Ang2 inhibition with cytotoxic drugs, or agents targeting the VEGFA pathway has shown significantly enhanced efficacy when compared to monotherapy (Brown et al. 2010; Hashizume et al. 2010; Huang et al. 2011; Daly et al. 2013). Interestingly, Ang2 overexpression in a mouse model of glioma inhibited the beneficial effects of anti-VEGFR-2 treatment on tumor vessel normalization, brain edema, 
M. Jeltsch et al.

and animal survival by increasing vascular permeability (Chae et al. 2010). This suggests that high Ang2 levels may compromise the efficacy of anti-VEGF-A therapy and that combinatorial inhibition of Ang2 and VEGF-A signaling should be further investigated. To this end, a chimeric decoy receptor, DAAP (double antiangiogenic protein), simultaneously capable of blocking mouse VEGF-A and angiopoietins, was shown to induce regression of tumor vessels, inhibition of metastasis, reduced ascites formation, and vascular leakage (Koh et al. 2010).

Other specific angiopoietin neutralizing agents that have been used in preclinical models include the soluble Tie2 ectodomain fused to the Fc domain of human immunoglobulin, which binds both Ang1 and Ang2 ligands (Lin et al. 1998), and an Ang2-specific aptamer (Sarraf-Yazdi et al. 2008); however, their clinical applicability is not yet clear.

Currently, several agents targeting the AngTie pathway are in clinical trials (see www. clinicaltrials.gov). A randomized, placebo-controlled phase-II trial showed that an Ang1 and Ang2 dual-specific peptibody (AMG 386) in combination with chemotherapy increased progression-free survival of patients with ovarian cancer (Karlan et al. 2012). The toxicity profile of AMG 386 was mild and distinct from that of VEGF-A inhibitors. Other Ang2-blocking agents, including a fully human anti-Ang2 monoclonal antibody MEDI 3617 (Leow et al. 2012), are currently being tested for safety, dose escalation, and efficacy in phase I/II clinical trials. CEP-11981, a Tie2 and VEGFR tyrosine kinase inhibitor with potential antiangiogenic and antineoplastic activities, is also being tested in clinical phase-I trials, but no information about its potential in tumor growth inhibition is yet available (Hudkins et al. 2012).

\section{CONCLUSIONS}

The endothelial cell-specific RTKs are the central effector molecules that orchestrate the development of the vasculature. Because of its omnipresence the vasculature is intimately involved in and affected by many disease processes. VEGF and Tie receptors have gathered most of the attention due to their central roles in tumor growth and progression. Detailed knowledge of these receptors and their functions has allowed the development of additional therapeutic agents against cancer and other diseases where angiogenesis is a contributor. Several drugs have been approved for the treatment of human cancers and certain eye diseases. However, the current data suggest that the existing drugs do not max out the possibilities of antiangiogenic therapy in cancer. Therefore, improved ("secondgeneration") antiangiogenic drugs are in development. On the flip side, the development of proangiogenic therapies, which could be beneficial in a variety of diseases characterized by insufficient angiogenesis, has not progressed to routine clinical applications. Because proand antiangiogenic therapies aim at antagonistic goals, there might be intrinsic limits to their applicability. Would the proangiogenic therapy of coronary heart disease increase the incidence of some types of tumors? Or would long-term antiangiogenic tumor therapy (e.g., to prevent reoccurrence) compromise the vascular health in a patient? To answer these questions we will have to learn more about the molecular basis of vascular biology and this knowledge in turn will allow at least incremental improvements of the existing therapeutic strategies as well as the design of new ones.

\section{REFERENCES}

Abdullah SE, Perez-Soler R. 2011. Mechanisms of resistance to vascular endothelial growth factor blockade. Cancer 118: 3455-3467.

Achen MG, Stacker SA. 2008. Molecular control of lymphatic metastasis. Ann NY Acad Sci 1131: 225-234.

Adams RH, Eichmann A. 2010. Axon guidance molecules in vascular patterning. Cold Spring Harb Perspect Biol 2: a001875.

Albuquerque RJC, Hayashi T, Cho WG, Kleinman ME, Dridi S, Takeda A, Baffi JZ, Yamada K, Kaneko H, Green MG, et al. 2009. Alternatively spliced vascular endothelial growth factor receptor-2 is an essential endogenous inhibitor of lymphatic vessel growth. Nat Med 15: 1023-1030.

Alders M, Hogan BM, Gjini E, Salehi F, Al-Gazali L, Hennekam EA, Holmberg EE, Mannens MM, Mulder MF, Offerhaus GJ, et al. 2009. Mutations in CCBE1 cause generalized lymph vessel dysplasia in humans. Nat Genet 41: $1272-1274$.

Alitalo K. 2011. The lymphatic vasculature in disease. Nat Med 17: 1371-1380. 
Andrae J, Gallini R, Betsholtz C. 2008. Role of platelet-derived growth factors in physiology and medicine. Genes Dev 22: 1276-1312.

Anisimov A, Alitalo A, Korpisalo P, Soronen J, Kaijalainen S, Leppänen V-M, Jeltsch M, Ylä-Herttuala S, Alitalo K. 2009. Activated forms of VEGF-C and VEGF-D provide improved vascular function in skeletal muscle. Circ Res 104: $1302-1312$.

Anisimov A, Tvorogov D, Alitalo A, Leppanen VM, An Y, Han EC, Orsenigo F, Gaal EI, Holopainen T, Koh YJ, et al. 2013. Vascular endothelial growth factor-angiopoietin chimera with improved properties for therapeutic angiogenesis. Circulation 127: 424-434.

Augustin HG. 2005. Angiogenesis in the female reproductive system. EXS 94: 35-52.

Augustin HG, Koh GY, Thurston G, Alitalo K. 2009. Control of vascular morphogenesis and homeostasis through the angiopoietin-Tie system. Nat Rev Mol Cell Biol 10: 165177.

Baeriswyl V, Christofori G. 2009. The angiogenic switch in carcinogenesis. Semin Cancer Biol 19: 329-337.

Baffert F, Le T, Thurston G, McDonald DM. 2006. Angiopoietin- 1 decreases plasma leakage by reducing number and size of endothelial gaps in venules. Am J Physiol Heart Circ Physiol 290: H107-H118.

Bais C, Wu X, Yao J, Yang S, Crawford Y, McCutcheon K, Tan C, Kolumam G, Vernes JM, Eastham-Anderson J, et al. 2010. PlGF blockade does not inhibit angiogenesis during primary tumor growth. Cell 141: 166-177.

Baldwin ME, Catimel B, Nice EC, Roufail S, Hall NE, Stenvers KL, Karkkainen MJ, Alitalo K, Stacker SA, Achen MG. 2001. The specificity of receptor binding by vascular endothelial growth factor-D is different in mouse and man. J Biol Chem 276: 19166-19171.

Baldwin ME, Halford MM, Roufail S, Williams RA, Hibbs ML, Grail D, Kubo H, Stacker SA, Achen MG. 2005. Vascular endothelial growth factor D is dispensable for development of the lymphatic system. Mol Cell Biol 25: 2441-2449.

Barton WA, Tzvetkova-Robev D, Miranda EP, Kolev MV, Rajashankar KR, Himanen JP, Nikolov DB. 2006. Crystal structures of the Tie2 receptor ectodomain and the angiopoietin-2-Tie2 complex. Nat Struct Mol Biol 13: 524532.

Bellomo D, Headrick JP, Silins GU, Paterson CA, Thomas PS, Gartside M, Mould A, Cahill MM, Tonks ID, Grimmond SM, et al. 2000. Mice lacking the vascular endothelial growth factor-B gene (Vegfb) have smaller hearts, dysfunctional coronary vasculature, and impaired recovery from cardiac ischemia. Circ Res 86: E29-E35.

Bhargava P, Robinson MO. 2011. Development of secondgeneration VEGFR tyrosine kinase inhibitors: Current status. Curr Oncol Rep 13: 103-111.

Bollinger A, Isenring G, Franzeck UK, Brunner U. 1983. Aplasia of superficial lymphatic capillaries in hereditary and connatal lymphedema (Milroy's disease). Lymphology 16: $27-30$.

Bos FL, Caunt M, Peterson-Maduro J, Planas-Paz L, Kowalski J, Karpanen T, van Impel A, Tong R, Ernst JA, Korving $\mathrm{J}$, et al. 2011. CCBE1 is essential for mammalian lymphatic vascular development and enhances the lymphangio- genic effect of vascular endothelial growth factor-C in vivo. Circ Res 109: 486-491.

Boulpaep EL. 2009. Arteries and veins. The microcirculation. Medical physiology: A cellular and molecular approach (ed. Boron WF, Boulpaep EL), pp. 467-503. Saunders Elsevier, Philadelphia.

Bremnes RM, Camps C, Sirera R. 2006. Angiogenesis in non-small cell lung cancer: The prognostic impact of neoangiogenesis and the cytokines VEGF and bFGF in tumours and blood. Lung Cancer 51: 143-158.

Brouillard P, Vikkula M. 2007. Genetic causes of vascular malformations. Hum Mol Genet 16 (Spec No. 2): R140R149.

Brown JL, Cao ZA, Pinzon-Ortiz M, Kendrew J, Reimer C, Wen S, Zhou JQ, Tabrizi M, Emery S, McDermott B, et al. 2010. A human monoclonal anti-ANG2 antibody leads to broad antitumor activity in combination with VEGF inhibitors and chemotherapy agents in preclinical models. Mol Cancer Ther 9: 145-156.

Bry M, Kivelä R, Holopainen T, Anisimov A, Tammela T, Soronen J, Silvola J, Saraste A, Jeltsch M, Korpisalo P, et al. 2010. Vascular endothelial growth factor-B acts as a coronary growth factor in transgenic rats without inducing angiogenesis, vascular leak, or inflammation. Circulation 122: $1725-1733$

Carmeliet P, Ferreira V, Breier G, Pollefeyt S, Kieckens L, Gertsenstein M, Fahrig M, Vandenhoeck A, Harpal K, Eberhardt C, et al. 1996. Abnormal blood vessel development and lethality in embryos lacking a single VEGF allele. Nature 380: 435-439.

Carmeliet P, Moons L, Luttun A, Vincenti V, Compernolle V, De Mol M, Wu Y, Bono F, Devy L, Beck H, et al. 2001. Synergism between vascular endothelial growth factor and placental growth factor contributes to angiogenesis and plasma extravasation in pathological conditions. Nat Med 7: 575-583.

Cascone I, Napione L, Maniero F, Serini G, Bussolino F. 2005. Stable interaction between $\alpha 5 \beta 1$ integrin and Tie2 tyrosine kinase receptor regulates endothelial cell response to Ang-1. J Cell Biol 170: 993-1004.

Caunt M, Mak J, Liang W-C, Stawicki S, Pan Q, Tong RK, Kowalski J, Ho C, Reslan HB, Ross J, et al. 2008. Blocking neuropilin-2 function inhibits tumor cell metastasis. Cancer Cell 13: 331-342.

Chae S-S, Kamoun WS, Farrar CT, Kirkpatrick ND, Niemeyer E, de Graaf AMA, Sorensen AG, Munn LL, Jain RK, Fukumura D. 2010. Angiopoietin-2 interferes with antiVEGFR2-induced vessel normalization and survival benefit in mice bearing gliomas. Clin Cancer Res 16: 3618-3627.

Chappell JC, Taylor SM, Ferrara N, Bautch VL. 2009. Local guidance of emerging vessel sprouts requires soluble Flt1. Dev Cell 17: 377-386.

Costa C, Incio Jo, Soares R. 2007. Angiogenesis and chronic inflammation: Cause or consequence? Angiogenesis 10: $149-166$.

Coxon A, Bready J, Min H, Kaufman S, Leal J, Yu D, Lee TA, Sun JR, Estrada J, Bolon B, et al. 2010. Context-dependent role of angiopoietin-1 inhibition in the suppression of angiogenesis and tumor growth: Implications for AMG 386, an angiopoietin-1/2-neutralizing peptibody. Mol Cancer Ther 9: 2641-2651. 
M. Jeltsch et al.

Daly C, Eichten A, Castanaro C, Pasnikowski E, Adler A, Lalani AS, Papadopoulos N, Kyle AH, Minchinton AI, Yancopoulos GD, et al. 2013. Angiopoietin-2 functions as a tie2 agonist in tumor models, where it limits the effects of VEGF inhibition. Cancer Res 73: 108-118.

D'Amico G, Korhonen EA, Waltari M, Saharinen P, Laakkonen P, Alitalo K. 2010. Loss of endothelial Tie1 receptor impairs lymphatic vessel development-brief report. Arterioscler Thromb Vasc Biol 30: 207-209.

David S, Mukherjee A, Ghosh CC, Yano M, Khankin EV, Wenger JB, Karumanchi SA, Shapiro NI, Parikh SM. 2012. Angiopoietin-2 may contribute to multiple organ dysfunction and death in sepsis. Crit Care Med 40: 30343041.

Davis S, Aldrich TH, Jones PF, Acheson A, Compton DL, Jain V, Ryan TE, Bruno J, Radziejewski C, Maisonpierre PC, et al. 1996. Isolation of angiopoietin-1, a ligand for the TIE2 receptor, by secretion-trap expression cloning. Cell 87: 1161-1169.

Dellinger M, Hunter R, Bernas M, Gale N, Yancopoulos G, Erickson R, Witte M. 2008. Defective remodeling and maturation of the lymphatic vasculature in Angiopoietin-2 deficient mice. Dev Biol 319: 309-320.

del Toro R, Prahst C, Mathivet T, Siegfried G, Kaminker JS, Larrivee B, Breant C, Duarte A, Takakura N, Fukamizu A, et al. 2010. Identification and functional analysis of endothelial tip cell-enriched genes. Blood 116: 4025-4033.

De Luca A, Normanno N. 2010. Tivozanib, a pan-VEGFR tyrosine kinase inhibitor for the potential treatment of solid tumors. IDrugs 13: 636-645.

Dumont DJ, Gradwohl G, Fong GH, Puri MC, Gertsenstein M, Auerbach A, Breitman ML. 1994. Dominant-negative and targeted null mutations in the endothelial receptor tyrosine kinase, tek, reveal a critical role in vasculogenesis of the embryo. Genes Dev 8: 1897-1909.

Dumont DJ, Jussila L, Taipale J, Lymboussaki A, Mustonen T, Pajusola K, Breitman M, Alitalo K. 1998. Cardiovascular failure in mouse embryos deficient in VEGF receptor3. Science 282: 946-949.

Ebos JML, Lee CR, Cruz-Munoz W, Bjarnason GA, Christensen JG, Kerbel RS. 2009. Accelerated metastasis after short-term treatment with a potent inhibitor of tumor angiogenesis. Cancer Cell 15: 232-239.

Escudier B, Eisen T, Stadler WM, Szczylik C, Oudard S, Siebels M, Negrier S, Chevreau C, Solska E, Desai AA, et al. 2007. Sorafenib in advanced clear-cell renal-cell carcinoma. N Engl J Med 356: 125-134.

Falcon BL, Hashizume H, Koumoutsakos P, Chou J, Bready JV, Coxon A, Oliner JD, McDonald DM. 2009. Contrasting actions of selective inhibitors of angiopoietin-1 and angiopoietin-2 on the normalization of tumor blood vessels. Am J Pathol 175: 2159-2170.

Fantin A, Vieira JM, Gestri G, Denti L, Schwarz Q, Prykhozhij S, Peri F, Wilson SW, Ruhrberg C. 2010. Tissue macrophages act as cellular chaperones for vascular anastomosis downstream of VEGF-mediated endothelial tip cell induction. Blood 116: 829-840.

Favier B, Alam A, Barron P, Bonnin J, Laboudie P, Fons P, Mandron M, Herault J-P, Neufeld G, Savi P, et al. 2006. Neuropilin-2 interacts with VEGFR-2 and VEGFR-3 and promotes human endothelial cell survival and migration. Blood 108: 1243-1250.
Felcht M, Luck R, Schering A, Seidel P, Srivastava K, Hu J, Bartol A, Kienast Y, Vettel C, Loos EK, et al. 2012. Angiopoietin-2 differentially regulates angiogenesis through TIE2 and integrin signaling. J Clin Invest 122: $1991-$ 2005.

Ferrara N. 2004. Vascular endothelial growth factor: Basic science and clinical progress. Endocr Rev 25: 581-611.

Ferrara N. 2010. Role of myeloid cells in vascular endothelial growth factor-independent tumor angiogenesis. Curr Opin Hematol 17: 219-224.

Ferrara N, Carver-Moore K, Chen H, Dowd M, Lu L, O'Shea KS, Powell-Braxton L, Hillan KJ, Moore MW. 1996. Heterozygous embryonic lethality induced by targeted inactivation of the VEGF gene. Nature 380: 439-442.

Ferrara N, Hillan KJ, Novotny W. 2005. Bevacizumab (Avastin), a humanized anti-VEGF monoclonal antibody for cancer therapy. Biochem Biophys Res Commun 333: 328335.

Ferrara N, Mass RD, Campa C, Kim R. 2007. Targeting VEGF-A to treat cancer and age-related macular degeneration. Annu Rev Med 58: 491-504.

Fiedler U, Scharpfenecker M, Koidl S, Hegen A, Grunow V, Schmidt JM, Kriz W, Thurston G, Augustin HG. 2004. The Tie-2 ligand angiopoietin-2 is stored in and rapidly released upon stimulation from endothelial cell WeibelPalade bodies. Blood 103: 4150-4156.

Fiedler U, Reiss Y, Scharpfenecker M, Grunow V, Koidl S, Thurston G, Gale NW, Witzenrath M, Rosseau S, Suttorp N, et al. 2006. Angiopoietin-2 sensitizes endothelial cells to TNF- $\alpha$ and has a crucial role in the induction of inflammation. Nat Med 12: 235-239.

Fong GH, Rossant J, Gertsenstein M, Breitman ML. 1995. Role of the Flt- 1 receptor tyrosine kinase in regulating the assembly of vascular endothelium. Nature 376: 66-70.

Fong GH, Zhang L, Bryce DM, Peng J. 1999. Increased hemangioblast commitment, not vascular disorganization, is the primary defect in flt-1 knock-out mice. Development 126: 3015-3025.

Fukuhara S, Sako K, Minami T, Noda K, Kim HZ, Kodama T, Shibuya M, Takakura N, Koh GY, Mochizuki N. 2008. Differential function of Tie2 at cell-cell contacts and cell-substratum contacts regulated by angiopoietin-1. Nat Cell Biol 10: 513-526.

Füller T, Korff T, Kilian A, Dandekar G, Augustin HG. 2003. Forward EphB4 signaling in endothelial cells controls cellular repulsion and segregation from ephrinB2 positive cells. J Cell Sci 116: 2461-2470.

Gale NW, Thurston G, Hackett SF, Renard R, Wang Q, McClain J, Martin C, Witte C, Witte MH, Jackson D, et al. 2002. Angiopoietin-2 is required for postnatal angiogenesis and lymphatic patterning, and only the latter role is rescued by Angiopoietin-1. Dev Cell 3: 411-423.

Galvagni F, Pennacchini S, Salameh A, Rocchigiani M, Neri F, Orlandini M, Petraglia F, Gotta S, Sardone GL, Matteucci G, et al. 2010. Endothelial cell adhesion to the extracellular matrix induces c-Src-dependent VEGFR-3 phosphorylation without the activation of the receptor intrinsic kinase activity. Circ Res 106: 1839-1848.

Gerber HP, Kowalski J, Sherman D, Eberhard DA, Ferrara N. 2000. Complete inhibition of rhabdomyosarcoma xenograft growth and neovascularization requires blockade of 
Receptor Tyrosine Kinase-Mediated Angiogenesis

both tumor and host vascular endothelial growth factor. Cancer Res 60: 6253-6258.

Gerhardt H, Ruhrberg C, Abramsson A, Fujisawa H, Shima D, Betsholtz C. 2004. Neuropilin-1 is required for endothelial tip cell guidance in the developing central nervous system. Dev Dyn 231: 503-509.

Germain S, Monnot C, Muller L, Eichmann A. 2010. Hypoxia-driven angiogenesis: Role of tip cells and extracellular matrix scaffolding. Curr Opin Hematol 17: 245251.

Goede V, Coutelle O, Neuneier J, Reinacher-Schick A, Schnell R, Koslowsky TC, Weihrauch MR, Cremer B, Kashkar H, Odenthal M, et al. 2010. Identification of serum angiopoietin-2 as a biomarker for clinical outcome of colorectal cancer patients treated with bevacizumab-containing therapy. Br J Cancer 103: 1407-1414.

Gordon K, Schulte D, Brice G, Simpson MA, Roukens MG, van Impel A, Connell F, Kalidas K, Jeffery S, Mortimer PS, et al. 2013. Mutation in vascular endothelial growth factor-C, a ligand for vascular endothelial growth factor receptor-3, is associated with autosomal dominant milroy-like primary lymphedema. Circ Res 112: 956-960.

Goyal S, Chauhan SK, Dana R. 2012. Blockade of prolymphangiogenic vascular endothelial growth factor $\mathrm{C}$ in dry eye disease. Arch Ophthalmol 130: 84-89.

Graeber TG, Osmanian C, Jacks T, Housman DE, Koch CJ, Lowe SW, Giaccia AJ. 1996. Hypoxia-mediated selection of cells with diminished apoptotic potential in solid tumours. Nature 379: 88-91.

Hagerling R, Pollmann C, Andreas M, Schmidt C, Nurmi H, Adams RH, Alitalo K, Andresen V, Schulte-Merker S, Kiefer F. 2013. A novel multistep mechanism for initial lymphangiogenesis in mouse embryos based on ultramicroscopy. EMBO J 32: 629-644.

Haiko P, Makinen T, Keskitalo S, Taipale J, Karkkainen MJ, Baldwin ME, Stacker SA, Achen MG, Alitalo K. 2008. Deletion of vascular endothelial growth factor $C$ (VEGF-C) and VEGF-D is not equivalent to VEGF receptor 3 deletion in mouse embryos. Mol Cell Biol 28: 4843-4850.

Hammes H-P, Lin J, Wagner P, Feng Y, Vom Hagen F, Krzizok T, Renner O, Breier G, Brownlee M, Deutsch U. 2004. Angiopoietin-2 causes pericyte dropout in the normal retina: Evidence for involvement in diabetic retinopathy. Diabetes 53: 1104-1110.

Hanahan D, Christofori G, Naik P, Arbeit J. 1996. Transgenic mouse models of tumour angiogenesis: The angiogenic switch, its molecular controls, and prospects for preclinical therapeutic models. Eur J Cancer 32A: 2386-2393.

Hashizume H, Falcon BL, Kuroda T, Baluk P, Coxon A, Yu D, Bready JV, Oliner JD, McDonald DM. 2010. Complementary actions of inhibitors of angiopoietin-2 and VEGF on tumor angiogenesis and growth. Cancer Res 70: 2213-2223.

He Y, Kozaki K-I, Karpanen T, Koshikawa K, Yla-Herttuala S, Takahashi T, Alitalo K. 2002. Suppression of tumor lymphangiogenesis and lymph node metastasis by blocking vascular endothelial growth factor receptor 3 signaling. J Natl Cancer Inst 94: 819-825.

He Y, Rajantie I, Ilmonen M, Makinen T, Karkkainen MJ, Haiko P, Salven P, Alitalo K. 2004. Preexisting lymphatic endothelium but not endothelial progenitor cells are es- sential for tumor lymphangiogenesis and lymphatic metastasis. Cancer Res 64: 3737-3740.

He Y, Rajantie I, Pajusola K, Jeltsch M, Holopainen T, YlaHerttuala S, Harding T, Jooss K, Takahashi T, Alitalo K. 2005. Vascular endothelial cell growth factor receptor 3mediated activation of lymphatic endothelium is crucial for tumor cell entry and spread via lymphatic vessels. Cancer Res 65: 4739-4746.

Hiratsuka S, Minowa O, Kuno J, Noda T, Shibuya M. 1998. Flt-1 lacking the tyrosine kinase domain is sufficient for normal development and angiogenesis in mice. Proc Natl Acad Sci 95: 9349-9354.

Ho VC, Duan LJ, Cronin C, Liang BT, Fong GH. 2012. Elevated vascular endothelial growth factor receptor-2 abundance contributes to increased angiogenesis in vascular endothelial growth factor receptor-1-deficient mice. Circulation 126: 741-752.

Hogan BM, Bos FL, Bussmann J, Witte M, Chi NC, Duckers HJ, Schulte-Merker S. 2009. Ccbel is required for embryonic lymphangiogenesis and venous sprouting. Nat $\mathrm{Ge}-$ net 41: 396-398.

Holash J, Maisonpierre PC, Compton D, Boland P, Alexander CR, Zagzag D, Yancopoulos GD, Wiegand SJ. 1999. Vessel cooption, regression, and growth in tumors mediated by angiopoietins and VEGF. Science 284: 19941998.

Holash J, Davis S, Papadopoulos N, Croll SD, Ho L, Russell M, Boland P, Leidich R, Hylton D, Burova E, et al. 2002. VEGF-Trap: AVEGF blocker with potent antitumor effects. Proc Natl Acad Sci 99: 11393-11398.

Holopainen T, Saharinen P, D’Amico G, Lampinen A, Eklund L, Sormunen R, Anisimov A, Zarkada G, Lohela M, Helotera H, et al. 2012. Effects of angiopoietin-2blocking antibody on endothelial cell-cell junctions and lung metastasis. J Natl Cancer Inst 104: 461-475.

Huang J, Bae J-O, Tsai JP, Kadenhe-Chiweshe A, Papa J, Lee A, Zeng S, Kornfeld ZN, Ullner P, Zaghloul N, et al. 2009. Angiopoietin-1/Tie-2 activation contributes to vascular survival and tumor growth during VEGF blockade. Int $J$ Oncol 34: 79-87.

Huang H, Lai J-Y, Do J, Liu D, Li L, Del Rosario J, Doppalapudi VR, Pirie-Shepherd S, Levin N, Bradshaw C, et al. 2011. Specifically targeting angiopoietin-2 inhibits angiogenesis, Tie2-expressing monocyte infiltration, and tumor growth. Clin Cancer Res 17: 1001-1011.

Hudkins RL, Becknell NC, Zulli AL, Underiner TL, Angeles TS, Aimone LD, Albom MS, Chang H, Miknyoczki SJ, Hunter K, et al. 2012. Synthesis and biological profile of the pan-vascular endothelial growth factor receptor/tyrosine kinase with immunoglobulin and epidermal growth factor-like homology domains 2 (VEGF-R/ TIE-2) inhibitor 11-(2-methylpropyl)-12,13-dihydro2-methyl-8-(pyrimidin-2-ylamino)-4H-inda zolo[5,4-a] pyrrolo[3,4-c] carbazol-4-one (CEP-11981): A novel oncology therapeutic agent. J Med Chem 55: 903-913.

Hurwitz H, Fehrenbacher L, Novotny W, Cartwright T, Hainsworth J, Heim W, Berlin J, Baron A, Griffing S, Holmgren E, et al. 2004. Bevacizumab plus irinotecan, fluorouracil, and leucovorin for metastatic colorectal cancer. N Engl J Med 350: 2335-2342.

Hwang J-A, Lee EH, Kim H-W, Park JB, Jeon BH, Cho C-H. 2009. COMP-Angl potentiates the antitumor activity of 
M. Jeltsch et al.

5-fluorouracil by improving tissue perfusion in murine Lewis lung carcinoma. Mol Cancer Res 7: 1920-1927.

Hyde CA, Giese A, Stuttfeld E, Abram Saliba J, Villemagne D, Schleier T, Binz HK, Ballmer-Hofer K. 2012. Targeting extracellular domains D4 and D7 of vascular endothelial growth factor receptor 2 reveals allosteric receptor regulatory sites. Mol Cell Biol 32: 3802-3813.

Jain RK. 2005. Normalization of tumor vasculature: An emerging concept in antiangiogenic therapy. Science 307: $58-62$.

Jakobsson L, Bentley K, Gerhardt H. 2009. VEGFRs and Notch: A dynamic collaboration in vascular patterning. Biochem Soc Trans 37: 1233-1236.

Janse AJ, van Coevorden F, Peterse H, Keus RB, van Dongen JA. 1995. Lymphedema-induced lymphangiosarcoma. Eur J Surg Oncol 21: 155-158.

Jeansson M, Gawlik A, Anderson G, Li C, Kerjaschki D, Henkelman M, Quaggin SE. 2011. Angiopoietin-1 is essential in mouse vasculature during development and in response to injury. J Clin Invest 121: 2278-2289.

Jeltsch M, Tammela T, Alitalo K, Wilting J. 2003. Genesis and pathogenesis of lymphatic vessels. Cell Tissue Res 314: 69-84.

Joukov V, Sorsa T, Kumar V, Jeltsch M, Claesson-Welsh L, Cao Y, Saksela O, Kalkkinen N, Alitalo K. 1997. Proteolytic processing regulates receptor specificity and activity of VEGF-C. EMBO J 16: 3898-3911.

Kaipainen A, Korhonen J, Mustonen T, van Hinsbergh VW, Fang GH, Dumont D, Breitman M, Alitalo K. 1995. Expression of the fms-like tyrosine kinase 4 gene becomes restricted to lymphatic endothelium during development. Proc Natl Acad Sci 92: 3566-3570.

Karkkainen MJ, Ferrell RE, Lawrence EC, Kimak MA, Levinson KL, McTigue MA, Alitalo K, Finegold DN. 2000. Missense mutations interfere with VEGFR-3 signalling in primary lymphoedema. Nat Genet 25: 153-159.

Karkkainen MJ, Saaristo A, Jussila L, Karila KA, Lawrence EC, Pajusola K, Bueler H, Eichmann A, Kauppinen R, Kettunen MI, et al. 2001. A model for gene therapy of human hereditary lymphedema. Proc Natl Acad Sci 98: 12677-12682.

Karkkainen MJ, Haiko P, Sainio K, Partanen J, Taipale J, Petrova TV, Jeltsch M, Jackson DG, Talikka M, Rauvala $\mathrm{H}$, et al. 2004. Vascular endothelial growth factor C is required for sprouting of the first lymphatic vessels from embryonic veins. Nat Immunol 5: 74-80.

Karlan BY, Oza AM, Richardson GE, Provencher DM, Hansen VL, Buck M, Chambers SK, Ghatage P, Pippitt CH Jr, Brown JV III, et al. 2012. Randomized, double-blind, placebo-controlled phase II study of AMG 386 combined with weekly paclitaxel in patients with recurrent ovarian cancer. J Clin Oncol 30: 362-371.

Karpanen T, Egeblad M, Karkkainen MJ, Kubo H, Ylä-Herttuala S, Jäättelä M, Alitalo K. 2001. Vascular endothelial growth factor $\mathrm{C}$ promotes tumor lymphangiogenesis and intralymphatic tumor growth. Cancer Res 61: 17861790.

Karpanen T, Wirzenius M, Mäkinen T, Veikkola T, Haisma HJ, Achen MG, Stacker SA, Pytowski B, Ylä-Herttuala S, Alitalo K. 2006. Lymphangiogenic growth factor responsiveness is modulated by postnatal lymphatic vessel maturation. Am J Pathol 169: 708-718.
Kearney JB, Ambler CA, Monaco KA, Johnson N, Rapoport RG, Bautch VL. 2002. Vascular endothelial growth factor receptor Flt-1 negatively regulates developmental blood vessel formation by modulating endothelial cell division. Blood 99: 2397-2407.

Kendall RL, Thomas KA. 1993. Inhibition of vascular endothelial cell growth factor activity by an endogenously encoded soluble receptor. Proc Natl Acad Sci 90: 1070510709.

Kendrew J, Eberlein C, Hedberg B, McDaid K, Smith NR, Weir HM, Wedge SR, Blakey DC, Foltz I, Zhou J, et al. 2011. An antibody targeted to VEGFR-2 Ig domains 4-7 inhibits VEGFR-2 activation and VEGFR-2-dependent angiogenesis without affecting ligand binding. Mol Cancer Ther 10: 770-783.

Kim KJ, Li B, Winer J, Armanini M, Gillett N, Phillips HS, Ferrara N. 1993. Inhibition of vascular endothelial growth factor-induced angiogenesis suppresses tumour growth in vivo. Nature 362: 841-844.

Kim I, Kwak HJ, Ahn JE, So JN, Liu M, Koh KN, Koh GY. 1999. Molecular cloning and characterization of a novel angiopoietin family protein, angiopoietin-3. FEBS Lett 443: 353-356.

Kim KT, Choi HH, Steinmetz MO, Maco B, Kammerer RA, Ahn SY, Kim HZ, Lee GM, Koh GY. 2005. Oligomerization and multimerization are critical for angiopoietin-1 to bind and phosphorylate Tie2. J Biol Chem 280: 2012620131.

Kim HA, Mahato RI, Lee M. 2009. Hypoxia-specific gene expression for ischemic disease gene therapy. Adv Drug Deliv Rev 61: 614-622.

Kleinman ME, Greives MR, Churgin SS, Blechman KM, Chang EI, Ceradini DJ, Tepper OM, Gurtner GC. 2007. Hypoxia-induced mediators of stem/progenitor cell trafficking are increased in children with hemangioma. Arterioscler Thromb Vasc Biol 27: 2664-2670.

Koch S, Tugues S, Li X, Gualandi L, Claesson-Welsh L. 2011. Signal transduction by vascular endothelial growth factor receptors. Biochem J 437: 169-183.

Koh YJ, Kim H-Z, Hwang S-I, Lee JE, Oh N, Jung K, Kim M, Kim KE, Kim H, Lim N-K, et al. 2010. Double antiangiogenic protein, DAAP, targeting VEGF-A and angiopoietins in tumor angiogenesis, metastasis, and vascular leakage. Cancer Cell 18: 171-184.

Lacorre D-A, Baekkevold ES, Garrido I, Brandtzaeg P, Haraldsen G, Amalric Fo, Girard J-P. 2004. Plasticity of endothelial cells: Rapid dedifferentiation of freshly isolated high endothelial venule endothelial cells outside the lymphoid tissue microenvironment. Blood 103: 4164-4172.

Lee HJ, Cho C-H, Hwang S-J, Choi H-H, Kim K-T, Ahn SY, Kim J-H, Oh J-L, Lee GM, Koh GY. 2004. Biological characterization of angiopoietin-3 and angiopoietin-4. FASEB J 18: 1200-1208.

Leow CC, Coffman K, Inigo I, Breen S, Czapiga M, Soukharev S, Gingles N, Peterson N, Fazenbaker C, Woods R, et al. 2012. MEDI3617, a human anti-angiopoietin 2 monoclonal antibody, inhibits angiogenesis and tumor growth in human tumor xenograft models. Int J Oncol 40: $1321-1330$.

Leppanen VM, Jeltsch M, Anisimov A, Tvorogov D, Aho K, Kalkkinen N, Toivanen P, Yla-Herttuala S, Ballmer-Hofer K, Alitalo K. 2011. Structural determinants of vascular 
endothelial growth factor-D receptor binding and specificity. Blood 117: 1507-1515.

Li X, Stankovic M, Bonder CS, Hahn CN, Parsons M, Pitson SM, Xia P, Proia RL, Vadas MA, Gamble JR. 2008a. Basal and angiopoietin-1-mediated endothelial permeability is regulated by sphingosine kinase-1. Blood 111: 34893497.

Li X, Tjwa M, Van Hove I, Enholm B, Neven E, Paavonen K, Jeltsch M, Juan TD, Sievers RE, Chorianopoulos E, et al. 2008b. Reevaluation of the role of VEGF-B suggests a restricted role in the revascularization of the ischemic myocardium. Arterioscler Thromb Vasc Biol 28: 16141620.

Limaye N, Wouters V, Uebelhoer M, Tuominen M, Wirkkala R, Mulliken JB, Eklund L, Boon LM, Vikkula M. 2009. Somatic mutations in angiopoietin receptor gene TEK cause solitary and multiple sporadic venous malformations. Nat Genet 41: 118-124.

Lin P, Buxton JA, Acheson A, Radziejewski C, Maisonpierre PC, Yancopoulos GD, Channon KM, Hale LP, Dewhirst MW, George SE, et al. 1998. Antiangiogenic gene therapy targeting the endothelium-specific receptor tyrosine kinase Tie2. Proc Natl Acad Sci 95: 8829-8834.

Lin J, Lalani AS, Harding TC, Gonzalez M, Wu W-W, Luan B, Tu GH, Koprivnikar K, VanRoey MJ, He Y, et al. 2005. Inhibition of lymphogenous metastasis using adenoassociated virus-mediated gene transfer of a soluble VEGFR-3 decoy receptor. Cancer Res 65: 6901-6909.

Lindsay CR, MacPherson IR, Cassidy J. 2009. Current status of cediranib: The rapid development of a novel anti-angiogenic therapy. Future Oncol 5: 421-432.

Liu R, Li X, Tulpule A, Zhou Y, Scehnet JS, Zhang S, Lee JS Chaudhary PM, Jung J, Gill PS. 2010. KSHV-induced notch components render endothelial and mural cell characteristics and cell survival. Blood 115: 887-895.

Losordo DW, Vale PR, Hendel RC, Milliken CE, Fortuin FD, Cummings N, Schatz RA, Asahara T, Isner JM, Kuntz RE. 2002. Phase $1 / 2$ placebo-controlled, double-blind, doseescalating trial of myocardial vascular endothelial growth factor 2 gene transfer by catheter delivery in patients with chronic myocardial ischemia. Circulation 105: 2012 2018.

Lu D, Shen J, Vil MD, Zhang H, Jimenez X, Bohlen P, Witte L, Zhu Z. 2003. Tailoring in vitro selection for a picomolar affinity human antibody directed against vascular endothelial growth factor receptor 2 for enhanced neutralizing activity. J Biol Chem 278: 43496-43507.

Lugus JJ, Park C, Choi K. 2005. Developmental relationship between hematopoietic and endothelial cells. Immunol Res 32: 57-74.

Luttun A, Tjwa M, Moons L, Wu Y, Angelillo-Scherrer A, Liao F, Nagy JA, Hooper A, Priller J, De Klerck B, et al. 2002. Revascularization of ischemic tissues by PlGF treatment, and inhibition of tumor angiogenesis, arthritis and atherosclerosis by anti-Flt1. Nat Med 8: 831-840.

Macdonald PR, Progias P, Ciani B, Patel S, Mayer U, Steinmetz MO, Kammerer RA. 2006. Structure of the extracellular domain of Tie receptor tyrosine kinases and localization of the angiopoietin-binding epitope. J Biol Chem 281: 28408-28414.

Maisonpierre PC, Suri C, Jones PF, Bartunkova S, Wiegand SJ, Radziejewski C, Compton D, McClain J, Aldrich TH,
Papadopoulos N, et al. 1997. Angiopoietin-2, a natural antagonist for Tie2 that disrupts in vivo angiogenesis. Science 277: 55-60.

Makinen T, Jussila L, Veikkola T, Karpanen T, Kettunen MI, Pulkkanen KJ, Kauppinen R, Jackson DG, Kubo H, Nishikawa S, et al. 2001. Inhibition of lymphangiogenesis with resulting lymphedema in transgenic mice expressing soluble VEGF receptor-3. Nat Med 7: 199-205.

Mazzieri R, Pucci F, Moi D, Zonari E, Ranghetti A, Berti A, Politi LS, Gentner B, Brown JL, Naldini L, et al. 2011. Targeting the ANG2/TIE2 axis inhibits tumor growth and metastasis by impairing angiogenesis and disabling rebounds of proangiogenic myeloid cells. Cancer Cell 19: $512-526$.

Motzer RJ, Hutson TE, Tomczak P, Michaelson MD, Bukowski RM, Rixe O, Oudard S, Negrier S, Szczylik C, Kim ST, et al. 2007. Sunitinib versus interferon alfa in metastatic renal-cell carcinoma. N Engl J Med 356: 115-124.

Nasarre P, Thomas M, Kruse K, Helfrich I, Wolter V, Deppermann C, Schadendorf D, Thurston G, Fiedler U, Augustin HG. 2009. Host-derived angiopoietin-2 affects early stages of tumor development and vessel maturation but is dispensable for later stages of tumor growth. Cancer Res 69: 1324-1333.

Ng EW, Shima DT, Calias P, Cunningham ET Jr, Guyer DR, Adamis AP. 2006. Pegaptanib, a targeted anti-VEGF aptamer for ocular vascular disease. Nat Rev Drug Discov 5: $123-132$.

Nguyen QD, Brown DM, Marcus DM, Boyer DS, Patel S, Feiner L, Gibson A, Sy J, Rundle AC, Hopkins JJ, et al. 2012. Ranibizumab for diabetic macular edema: Results from 2 phase III randomized trials: RISE and RIDE. Ophthalmology 119: 789-801.

Nilsson I, Bahram F, Li X, Gualandi L, Koch S, Jarvius M, Soderberg O, Anisimov A, Kholova I, Pytowski B, et al. 2010. VEGF receptor 2/-3 heterodimers detected in situ by proximity ligation on angiogenic sprouts. $E M B O J \mathbf{2 9}$ : 1377-1388.

Nissen LJ, Cao R, Hedlund E-M, Wang Z, Zhao X, Wetterskog D, Funa K, Brakenhielm E, Cao Y. 2007. Angiogenic factors FGF2 and PDGF-BB synergistically promote murine tumor neovascularization and metastasis. J Clin Invest 117: 2766-2777.

Norrmén C, Tammela T, Petrova TV, Alitalo K. 2011. Biological basis of therapeutic lymphangiogenesis. Circulation 123: $1335-1351$.

North PE, Waner M, Buckmiller L, James CA, Mihm MCJ. 2006. Vascular tumors of infancy and childhood: Beyond capillary hemangioma. Cardiovasc Pathol 15: 303-317.

Ny A, Koch M, Schneider M, Neven E, Tong RT, Maity S, Fischer C, Plaisance S, Lambrechts D, Heligon C, et al. 2005. A genetic Xenopus laevis tadpole model to study lymphangiogenesis. Nat Med 11: 998-1004.

Olsson A-K, Dimberg A, Kreuger J, Claesson-Welsh L. 2006. VEGF receptor signalling - in control of vascular function. Nat Rev Mol Cell Biol 7: 359-371.

Pàez-Ribes M, Allen E, Hudock J, Takeda T, Okuyama H, Viñals F, Inoue M, Bergers G, Hanahan D, Casanovas O. 2009. Antiangiogenic therapy elicits malignant progression of tumors to increased local invasion and distant metastasis. Cancer Cell 15: 220-231. 
M. Jeltsch et al.

Pan Q, Chanthery Y, Liang W-C, Stawicki S, Mak J, Rathore N, Tong RK, Kowalski J, Yee SF, Pacheco G, et al. 2007. Blocking neuropilin-1 function has an additive effect with anti-VEGF to inhibit tumor growth. Cancer Cell 11: $53-67$.

Papadopoulos N, Martin J, Ruan Q, Rafique A, Rosconi MP, Shi E, Pyles EA, Yancopoulos GD, Stahl N, Wiegand SJ. 2012. Binding and neutralization of vascular endothelial growth factor (VEGF) and related ligands by VEGF Trap, ranibizumab and bevacizumab. Angiogenesis 15: 171185.

Papoutsi M, Tomarev SI, Eichmann A, Prols F, Christ B, Wilting J. 2001. Endogenous origin of the lymphatics in the avian chorioallantoic membrane. Dev Dyn 222: $238-251$.

Parikh SM, Mammoto T, Schultz A, Yuan HT, Christiani D, Karumanchi SA, Sukhatme VP. 2006. Excess circulating angiopoietin-2 may contribute to pulmonary vascular leak in sepsis in humans. PLoS Med 3: e46.

Partanen J, Armstrong E, Mäkelä TP, Korhonen J, Sandberg M, Renkonen R, Knuutila S, Huebner K, Alitalo K. 1992. A novel endothelial cell surface receptor tyrosine kinase with extracellular epidermal growth factor homology domains. Mol Cell Biol 12: 1698-1707.

Partanen J, Puri MC, Schwartz L, Fischer KD, Bernstein A, Rossant J. 1996. Cell autonomous functions of the receptor tyrosine kinase TIE in a late phase of angiogenic capillary growth and endothelial cell survival during murine development. Development 122: 3013-3021.

Partanen TA, Arola J, Saaristo A, Jussila L, Ora A, Miettinen M, Stacker SA, Achen MG, Alitalo K. 2000. VEGF-C and VEGF-D expression in neuroendocrine cells and their receptor, VEGFR-3, in fenestrated blood vessels in human tissues. FASEB J 14: 2087-2096.

Persaud K, Tille J-C, Liu M, Zhu Z, Jimenez X, Pereira DS, Miao H-Q, Brennan LA, Witte L, Pepper MS, et al. 2004. Involvement of the VEGF receptor 3 in tubular morphogenesis demonstrated with a human anti-human VEGFR-3 monoclonal antibody that antagonizes receptor activation by VEGF-C. J Cell Sci 117: 2745-2756.

Pietila R, Natynki M, Tammela T, Kangas J, Pulkki KH, Limaye N, Vikkula M, Koh GY, Saharinen P, Alitalo K, et al. 2012. Ligand oligomerization state controls Tie2 receptor trafficking and angiopoietin-2-specific responses. J Cell Sci 125: 2212-2223.

Pipp F, Heil M, Issbrucker K, Ziegelhoeffer T, Martin S, van den Heuvel J, Weich H, Fernandez B, Golomb G, Carmeliet P, et al. 2003. VEGFR-1-selective VEGF homologue PIGF is arteriogenic: Evidence for a monocyte-mediated mechanism. Circ Res 92: 378-385.

Prior BM, Yang HT, Terjung RL. 2004. What makes vessels grow with exercise training? J Appl Physiol 97: 11191128.

Przewratil Pa, Sitkiewicz A, Andrzejewska E. 2010. Local serum levels of vascular endothelial growth factor in infantile hemangioma: Intriguing mechanism of endothelial growth. Cytokine 49: 141-147.

Puri MC, Rossant J, Alitalo K, Bernstein A, Partanen J. 1995. The receptor tyrosine kinase TIE is required for integrity and survival of vascular endothelial cells. EMBO J 14: 5884-5891.
Puri MC, Partanen J, Rossant J, Bernstein A. 1999. Interaction of the TEK and TIE receptor tyrosine kinases during cardiovascular development. Development 126: 45694580.

Qu X, Tompkins K, Batts LE, Puri M, Baldwin S. 2010. Abnormal embryonic lymphatic vessel development in Tiel hypomorphic mice. Development 137: 1285-1295.

Quinn TP, Peters KG, De Vries C, Ferrara N, Williams LT. 1993. Fetal liver kinase 1 is a receptor for vascular endothelial growth factor and is selectively expressed in vascular endothelium. Proc Natl Acad Sci 90: 7533-7537.

Reilly JP, Grise MA, Fortuin FD, Vale PR, Schaer GL, Lopez J, VAN Camp JR, Henry T, Richenbacher WE, Losordo DW, et al. 2005. Long-term (2-year) clinical events following transthoracic intramyocardial gene transfer of VEGF- 2 in no-option patients. J Interv Cardiol 18: 27-31.

Reiss Y, Knedla A, Tal AO, Schmidt MHH, Jugold M, Kiessling F, Burger AM, Wolburg H, Deutsch U, Plate KH. 2009. Switching of vascular phenotypes within a murine breast cancer model induced by angiopoietin-2.J Pathol 217: $571-580$.

Roberts N, Kloos B, Cassella M, Podgrabinska S, Persaud K, Wu Y, Pytowski B, Skobe M. 2006. Inhibition of VEGFR-3 activation with the antagonistic antibody more potently suppresses lymph node and distant metastases than inactivation of VEGFR-2. Cancer Res 66: 2650-2657.

Rosenfeld PJ, Rich RM, Lalwani GA. 2006. Ranibizumab: Phase III clinical trial results. Ophthalmol Clin North Am 19: $361-372$.

Ruhrberg C, Gerhardt H, Golding M, Watson R, Ioannidou S, Fujisawa H, Betsholtz C, Shima DT. 2002. Spatially restricted patterning cues provided by heparin-binding VEGF-A control blood vessel branching morphogenesis. Genes Dev 16: 2684-2698.

Saharinen P, Kerkelä K, Ekman N, Marron M, Brindle N, Lee GM, Augustin H, Koh GY, Alitalo K. 2005. Multiple angiopoietin recombinant proteins activate the Tiel receptor tyrosine kinase and promote its interaction with Tie2. J Cell Biol 169: 239-243.

Saharinen P, Eklund L, Miettinen J, Wirkkala R, Anisimov A, Winderlich M, Nottebaum A, Vestweber D, Deutsch U, Koh GY, et al. 2008. Angiopoietins assemble distinct Tie2 signalling complexes in endothelial cell-cell and cell-matrix contacts. Nat Cell Biol 10: 527-537.

Saharinen P, Eklund L, Pulkki K, Bono P, Alitalo K. 2011. VEGF and angiopoietin signaling in tumor angiogenesis and metastasis. Trends Mol Med 17: 347-362.

Sarraf-Yazdi S, Mi J, Moeller BJ, Niu X, White RR, Kontos CD, Sullenger BA, Dewhirst MW, Clary BM. 2008. Inhibition of in vivo tumor angiogenesis and growth via systemic delivery of an angiopoietin 2-specific RNA aptamer. J Surg Res 146: 16-23.

Sato TN, Tozawa Y, Deutsch U, Wolburg-Buchholz K, Fujiwara Y, Gendron-Maguire M, Gridley T, Wolburg H, Risau W, Qin Y. 1995. Distinct roles of the receptor tyrosine kinases Tie-1 and Tie-2 in blood vessel formation. Nature 376: $70-74$.

Seegar TC, Eller B, Tzvetkova-Robev D, Kolev MV, Henderson SC, Nikolov DB, Barton WA. 2010. Tie1-Tie2 interactions mediate functional differences between angiopoietin ligands. Mol Cell 37: 643-655. 
Receptor Tyrosine Kinase-Mediated Angiogenesis

Sennino B, McDonald DM. 2012. Controlling escape from angiogenesis inhibitors. Nat Rev Cancer 12: 699-709.

Shalaby F, Rossant J, Yamaguchi TP, Gertsenstein M, Wu XF, Breitman ML, Schuh AC. 1995. Failure of blood-island formation and vasculogenesis in Flk-1-deficient mice. Nature 376: 62-66.

Shibuya M, Claesson-Welsh L. 2006. Signal transduction by VEGF receptors in regulation of angiogenesis and lymphangiogenesis. Exp Cell Res 312: 549-560.

Singh M, Ferrara N. 2012. Modeling and predicting clinical efficacy for drugs targeting the tumor milieu. Nat Biotechnol 30: 648-657.

Sleijfer S, Ray-Coquard I, Papai Z, Le Cesne A, Scurr M, Schoffski P, Collin F, Pandite L, Marreaud S, De Brauwer A, et al. 2009. Pazopanib, a multikinase angiogenesis inhibitor, in patients with relapsed or refractory advanced soft tissue sarcoma: A phase II study from the European organization for research and treatment of cancer-soft tissue and bone sarcoma group (EORTC study 62043). J Clin Oncol 27: 3126-3132.

Snuderl M, Batista A, Kirkpatrick ND, Ruiz de Almodovar C, Riedemann L, Walsh EC, Anolik R, Huang Y, Martin JD, Kamoun W, et al. 2013. Targeting placental growth factor/neuropilin 1 pathway inhibits growth and spread of medulloblastoma. Cell 152: 1065-1076.

Stacker SA, Stenvers K, Caesar C, Vitali A, Domagala T, Nice E, Roufail S, Simpson RJ, Moritz R, Karpanen T, et al. 1999. Biosynthesis of vascular endothelial growth factorD involves proteolytic processing which generates noncovalent homodimers. J Biol Chem 274: 32127-32136.

Stacker SA, Achen MG, Jussila L, Baldwin ME, Alitalo K. 2002. Lymphangiogenesis and cancer metastasis. Nat Rev Cancer 2: 573-583.

Stewart DJ, Kutryk MJB, Fitchett D, Freeman M, Camack N, Su Y, Della Siega A, Bilodeau L, Burton JR, Proulx G, et al. 2009. VEGF gene therapy fails to improve perfusion of ischemic myocardium in patients with advanced coronary disease: Results of the NORTHERN trial. Mol Ther 17: 1109-1115.

Suri C, Jones PF, Patan S, Bartunkova S, Maisonpierre PC, Davis S, Sato TN, Yancopoulos GD. 1996. Requisite role of angiopoietin-1, a ligand for the TIE2 receptor, during embryonic angiogenesis. Cell 87: 1171-1180.

Tabruyn SP, Colton K, Morisada T, Fuxe J, Wiegand SJ, Thurston G, Coyle AJ, Connor J, McDonald DM. 2010. Angiopoietin-2-driven vascular remodeling in airway inflammation. Am J Pathol 177: 3233-3243.

Tammela T, Alitalo K. 2010. Lymphangiogenesis: Molecular mechanisms and future promise. Cell 140: 460-476.

Tammela T, Saaristo A, Holopainen T, Lyytikkä J, Kotronen A, Pitkonen M, Abo-Ramadan U, Ylä-Herttuala S, Petrova TV, Alitalo K. 2007. Therapeutic differentiation and maturation of lymphatic vessels after lymph node dissection and transplantation. Nat Med 13: 1458-1466.

Tammela T, Zarkada G, Wallgard E, Murtomaki A, Suchting S, Wirzenius M, Waltari M, Hellstrom M, Schomber T, Peltonen R, et al. 2008. Blocking VEGFR-3 suppresses angiogenic sprouting and vascular network formation. Nature 454: 656-660.

Tammela T, Saaristo A, Holopainen T, Ylä-Herttuala S, Andersson LC, Virolainen S, Immonen I, Alitalo K. 2011a. Photodynamic ablation of lymphatic vessels and intra- lymphatic cancer cells prevents metastasis. Sci Transl Med 3: 69ra11.

Tammela T, Zarkada G, Nurmi H, Jakobsson L, Heinolainen K, Tvorogov D, Zheng W, Franco CA, Murtomaki A, Aranda E, et al. 2011b. VEGFR-3 controls tip to stalk conversion at vessel fusion sites by reinforcing Notch signalling. Nat Cell Biol 13: 1202-1213.

Teng LS, Jin KT, He KF, Zhang J, Wang HH, Cao J. 2010. Clinical applications of VEGF-trap (aflibercept) in cancer treatment. J Chin Med Assoc 73: 449-456.

Thomas M, Felcht M, Kruse K, Kretschmer S, Deppermann C, Biesdorf A, Rohr K, Benest AV, Fiedler U, Augustin HG. 2010. Angiopoietin-2 stimulation of endothelial cells induces $\alpha v \beta 3$ integrin internalization and degradation. $J$ Biol Chem 285: 23842-23849.

Tonnesen MG, Feng X, Clark RA. 2000. Angiogenesis in wound healing. I Investig Dermatol Symp Proc 5: $40-46$.

Tvorogov D, Anisimov A, Zheng W, Leppänen V-M, Tammela T, Laurinavicius S, Holnthoner W, Heloterä H, Holopainen T, Jeltsch M, et al. 2010. Effective suppression of vascular network formation by combination of antibodies blocking VEGFR ligand binding and receptor dimerization. Cancer Cell 18: 630-640.

Valenzuela DM, Griffiths JA, Rojas J, Aldrich TH, Jones PF, Zhou H, McClain J, Copeland NG, Gilbert DJ, Jenkins NA, et al. 1999. Angiopoietins 3 and 4: Diverging gene counterparts in mice and humans. Proc Natl Acad Sci 96: $1904-1909$.

Van de Veire S, Stalmans I, Heindryckx F, Oura H, TijerasRaballand A, Schmidt T, Loges S, Albrecht I, Jonckx B, Vinckier S, et al. 2010. Further pharmacological and genetic evidence for the efficacy of PlGF inhibition in cancer and eye disease. Cell 141: 178-190.

Van Meter ME, Kim ES. 2010. Bevacizumab: Current updates in treatment. Curr Opin Oncol 22: 586-591.

Vikkula M, Boon LM, Carraway KLr, Calvert JT, Diamonti AJ, Goumnerov B, Pasyk KA, Marchuk DA, Warman ML, Cantley LC, et al. 1996. Vascular dysmorphogenesis caused by an activating mutation in the receptor tyrosine kinase TIE2. Cell 87: 1181-1190.

Virgili G, Parravano M, Menchini F, Brunetti M. 2012. Antiangiogenic therapy with anti-vascular endothelial growth factor modalities for diabetic macular oedema. Cochrane Database Syst Rev 12: CD007419.

Vuorio T, Jauhiainen S, Yla-Herttuala S. 2012. Pro- and antiangiogenic therapy and atherosclerosis with special emphasis on vascular endothelial growth factors. Exp Opin Biol Ther 12: 79-92.

Waltenberger J, Claesson-Welsh L, Siegbahn A, Shibuya M, Heldin CH. 1994. Different signal transduction properties of KDR and Flt1, two receptors for vascular endothelial growth factor. J Biol Chem 269: 26988-26995.

Weidner N, Semple JP, Welch WR, Folkman J. 1991. Tumor angiogenesis and metastasis-correlation in invasive breast carcinoma. $N$ Engl J Med 324: 1-8.

Wigle JT, Oliver G. 1999. Prox1 function is required for the development of the murine lymphatic system. Cell $\mathbf{9 8 :}$ 769-778.

Winkler F, Kozin SV, Tong RT, Chae SS, Booth MF, Garkavtsev I, Xu L, Hicklin DJ, Fukumura D, di Tomaso E, et al. 
M. Jeltsch et al.

2004. Kinetics of vascular normalization by VEGFR2 blockade governs brain tumor response to radiation: Role of oxygenation, angiopoietin-1, and matrix metalloproteinases. Cancer Cell 6: 553-563.

Xu Y, Yuan L, Mak J, Pardanaud L, Caunt M, Kasman I, Larrivée B, Del Toro R, Suchting S, Medvinsky A, et al. 2010. Neuropilin-2 mediates VEGF-C-induced lymphatic sprouting together with VEGFR3. J Cell Biol 188: 115130.

Yano K, Brown LF, Detmar M. 2001. Control of hair growth and follicle size by VEGF-mediated angiogenesis. J Clin Invest 107: 409-417.
Ylä-Herttuala S. 2009. Gene therapy with vascular endothelial growth factors. Biochem Soc Trans 37: 1198-1200.

Yu L, Liang XH, Ferrara N. 2011. Comparing protein VEGF inhibitors: In vitro biological studies. Biochem Biophys Res Commun 408: 276-281.

Zachary I, Morgan RD. 2011. Therapeutic angiogenesis for cardiovascular disease: Biological context, challenges, prospects. Heart 97: 181-189.

Zhang X, Groopman JE, Wang JF. 2005. Extracellular matrix regulates endothelial functions through interaction of VEGFR-3 and integrin $\alpha 5 \beta 1$. J Cell Physiol 202: 205-214. 


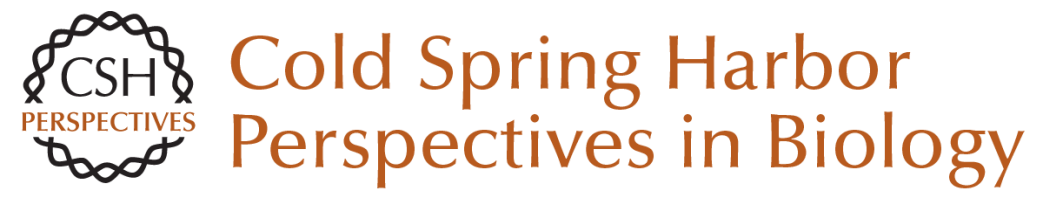

\section{Receptor Tyrosine Kinase-Mediated Angiogenesis}

Michael Jeltsch, Veli-Matti Leppänen, Pipsa Saharinen and Kari Alitalo

Cold Spring Harb Perspect Biol 2013; doi: 10.1101/cshperspect.a009183

Subject Collection Signaling by Receptor Tyrosine Kinases

CSF-1 Receptor Signaling in Myeloid Cells

E. Richard Stanley and Violeta Chitu

The EGFR Family: Not So Prototypical Receptor Tyrosine Kinases

Mark A. Lemmon, Joseph Schlessinger and Kathryn M. Ferguson

Tie2 and Eph Receptor Tyrosine Kinase Activation and Signaling

William A. Barton, Annamarie C. Dalton, Tom C.M. Seegar, et al.

The Spatiotemporal Organization of ErbB

Receptors: Insights from Microscopy

Christopher C. Valley, Keith A. Lidke and Diane S. Lidke

Insulin Receptor Signaling in Normal and Insulin-Resistant States

Jérémie Boucher, André Kleinridders and C. Ronald Kahn

Central Role of RET in Thyroid Cancer Massimo Santoro and Francesca Carlomagno

Receptor Tyrosine Kinase-Mediated Angiogenesis Michael Jeltsch, Veli-Matti Leppänen, Pipsa Saharinen, et al.

Biology of the TAM Receptors Greg Lemke

The Genesis of Tyrosine Phosphorylation Tony Hunter

Structure-Function Relationships of ErbB RTKs in the Plasma Membrane of Living Cells

Donna J. Arndt-Jovin, Michelle G. Botelho and Thomas M. Jovin

Receptor Tyrosine Kinases: Legacy of the First

Two Decades Joseph Schlessinger

The Role of Ryk and Ror Receptor Tyrosine Kinases in Wnt Signal Transduction Jennifer Green, Roel Nusse and Renée van Amerongen

Regulation of Receptor Tyrosine Kinase Ligand Processing Colin Adrain and Matthew Freeman

Molecular Mechanisms of SH2- and PTB-Domain-Containing Proteins in Receptor Tyrosine Kinase Signaling Melany J. Wagner, Melissa M. Stacey, Bernard A. Liu, et al.

Eph Receptor Signaling and Ephrins Erika M. Lisabeth, Giulia Falivelli and Elena B. Pasquale

Effects of Membrane Trafficking on Signaling by

Receptor Tyrosine Kinases Marta Miaczynska

For additional articles in this collection, see http://cshperspectives.cshlp.org/cgi/collection/

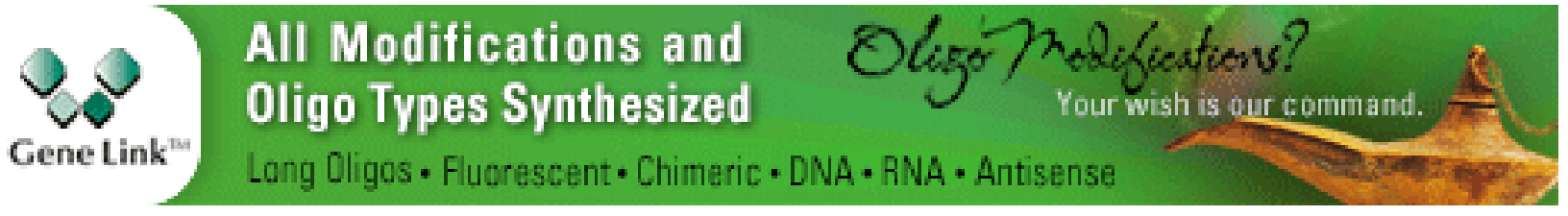

Copyright @ 2013 Cold Spring Harbor Laboratory Press; all rights reserved 
For additional articles in this collection, see http://cshperspectives.cshlp.org/cgi/collection/

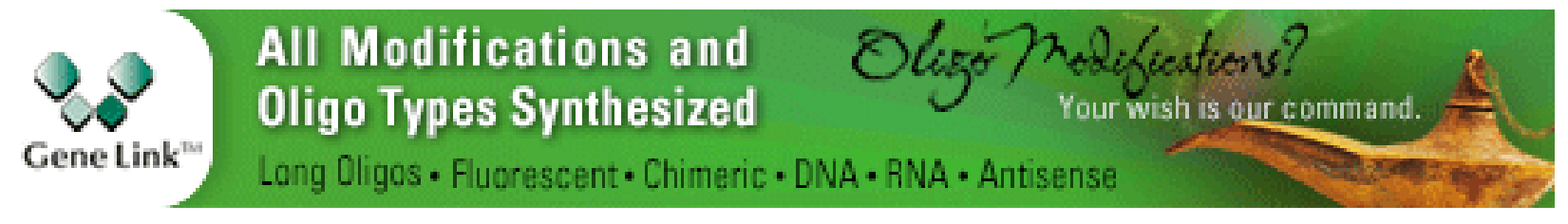

Copyright @ 2013 Cold Spring Harbor Laboratory Press; all rights reserved 